UNIVERSIDADE DE SÃO PAULO

FACULDADE DE FILOSOFIA, LETRAS E CIÊNCIAS HUMANAS

ERIKA INOUE NAGASE

A Inversão Locativa no Português Brasileiro

São Paulo

2007 


\section{A Inversão Locativa no Português Brasileiro}

Dissertação apresentada à Faculdade de Filosofia, Letras e Ciências Humanas da Universidade de São Paulo para obtenção do título de Mestre em Filologia e Língua Portuguesa.

Área de Concentração: Estudos Diacrônicos e Sincrônicos do Português.

Orientadora: Prof. $^{\mathrm{a}}$ Dr. $^{\mathrm{a}}$ Maria Aparecida C. R. Torres Morais

São Paulo 2007 


\section{Dedicatória}

A meus pais, Elena e Susumu, à minha irmã, Sheila;

A Felipe, a quem a vida me presenteou como um Grande Amor,

Num passe de mágica, a vida

Nos traz sonhos para seguir

Queima meus navios para eu me superar

Às vezes pedindo que ela vem nos dar

O melhor de si.

E quando vejo a vida espera mais de mim

Mais além,

Mais de mim...

O eterno aprendizado é o próprio fim.

Já nem sei

Se tem fim...

De elástica a minha alma dá de si

Mais além

Mais de mim..

(Jorge Vercilo, "Eu e a Vida")

com o melhor de mim. 


\section{Agradecimentos}

A Deus pela inspiração e discernimento durante todo o mestrado;

A meus pais, Elena e Susumu, e à minha irmã, Sheila, por todo o Amor, apoio e incentivo;

A Felipe pela paciência, Amor e doação constante;

À Prof ${ }^{\mathrm{a}}$. Cida pela orientação e paciência durante esses três anos e meio;

Às Prof ${ }^{\mathrm{as}}$. Sônia Cyrino e Marilza de Oliveira pelas sugestões e conselhos na minha banca de qualificação;

À Prof ${ }^{\mathrm{a}}$. Paula Kempchinsky da Universidade de Iowa por ter gentilmente me enviado seus trabalhos;

À Sandra Quarezemin da Universidade Federal de Santa Catarina pela ajuda e presteza com o material bibliográfico;

Aos amigos de pós, com saudades: Cássia Yamauchi, Andréa Colsato, Daday Salles, Adílson Góis da Cruz, Maria Maia Dantas, João de Vasconcellos e Bruno Maroneze (apesar de nossas divergências teóricas). 


\section{Resumo}

NAGASE, Erika Inoue. A Inversão Locativa no Português Brasileiro. Dissertação de mestrado. Universidade de São Paulo, FFLCH, São Paulo, 2007.

Palavras-chave:inversão locativa,topicalização de PPs,EPP, ordem VS, inversão do sujeito.

$\mathrm{Na}$ presente pesquisa analisamos as construções que envolvem as estruturas de IL sob a perspectiva da Teoria Gerativa em sua versão de Princípios e Parâmetros (Chomsky 1981, 1986). É considerado um fenômeno de inacusatividade e um fenômeno discursivo em línguas como o inglês e o espanhol. Sua estrutura padrão é a ordem PP V DP, em que o PP é um locativo (LOC) e o DP é um argumento tema em posição pós-verbal. Partimos de uma análise léxico-funcional de Bresnan (1994) que postula a Hipótese do Foco Apresentacional para explicar a função discursiva da construção. Em seguida, apresentamos a análise discursiva de Levin \& Rappaport Hovav (1995) que propõem a Hipótese do Verbo Informacionalmente Leve. A terceira análise traz uma visão minimalista recente sobre a construção através da descrição de fenômenos que se interrelacionam - a IL, a topicalização de PPs e o EPP. Para a análise da IL é fundamental investigar onde se coloca o PB atualmente dentro do parâmetro do sujeito nulo, como se dá a atribuição de Caso nominativo ao sujeito e em que contextos ocorre a inversão nessa língua. Assim, fazemos uma breve revisão da literatura do PB, partindo da Hipótese do Caso Partitivo, passando pela a Hipótese de Mono-Argumentalidade, até chegar nas sentenças com SUJs invertidos tanto com verbos mono-argumentais quanto com VTs. Referenciamos um dos primeiros trabalhos sobre a IL, em que Barbosa (1989) nos oferece algumas intuições iniciais para uma análise do fenômeno. Já Pilati (2002) descreve as construções de IL como um dos tipos de sentenças apresentativas e Quarezemin (2006) propõe que estas construções são motivadas por tal função discursiva pelo fato de seus SUJs serem interpretados como o FOC das sentenças. Em seguida, apresentamos uma proposta de análise para a IL, mostrando que há dois tipos de ILs - a IL propriamente dita e a IL discursiva. O último capítulo apresenta as considerações finais desta pesquisa, apontando algumas semelhanças entre a construção da IL e as construções de topicalização sem preposição. Mais do que propor uma análise para a IL no PB, nosso objetivo é mostrar a importância de tal fenômeno num âmbito maior dos estudos da gramática do PB, considerando que a IL pode ser uma pista que caracterizaria o PB como uma língua de traço EPP. 


\begin{abstract}
NAGASE, Erika Inoue. A Inversão Locativa no Português Brasileiro. Dissertação de mestrado. Universidade de São Paulo, FFLCH, São Paulo, 2007.

Key-words: locative inversion, topicalization of PPs, EPP, VS order, subject inversion.
\end{abstract}

In this dissertation we analyse constructions that involve inversion locative (IL) structures under the Government and Binding framework of the Generative Theory (Chomsky 1981, 1986). IL is considered an unaccusativity and discourse-like phenomenon in languages like English and Spanish. Its pattern structure is the order PP V DP, in which the PP is a locative and the DP is theme argument placed in postverbal position. We departure from a lexical functional analysis from Bresnan (1994) that postulates the Presentational Focus Hypothesis in order to explain the discourse-like function of the construction. In the sequence we present a dicourse-like analysis from Levin \& Rappaport Hovav (1995) that proposes the Informationally Light Verb Hypothesis. A third analysis brings a recent minimalist view of the construction through the description of some phenomena that are interrelated - the IL, the topicalization of PPs and the EPP. In order to analyse the IL in Brazilian Portuguese (BP) it is primordial to investigate where BP can be placed within the pro-drop parameter, how nominative Case can be assigned to the subject and in which contexts the inversion occurs in this language. Hence, we do a brief review of the BP literature, departuring from the partitive Case, going to the Intransitive Hypothesis up to sentences with inverted subjects with both intransitive and transitive verbs. We mention one of the first papers about IL in Portuguese, in which Barbosa (1989) offers us some intuitions for an analysis to this phenomenon. Pilati (2002) describes the IL constructions as presentational sentences and Quarezemin (2006) proposes that these constructions are motivated by a dicourse-like function since its subjects must be interpretated as the focus of the sentences. After that we present an analysis to the IL in BP, showing that there are two different kinds of IL - the IL itself and the discourse-like IL. The last chapter presents the conclusions of this research, pointing some similarities between the IL constructions and the topicalization of PPs. More than proposing an analysis to the IL in BP our goal is to show the importance of such phenomenon in a more general view of the BP grammatical studies, considering that IL can be a clue that would characterize BP as an EPP language. 


\section{Sumário}

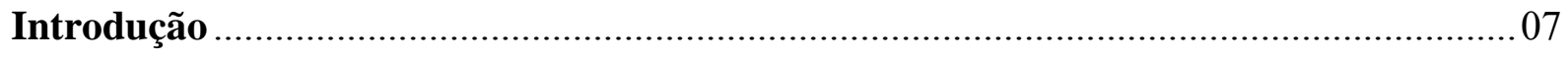

Capítulo 1: O Fenômeno da Inversão Locativa .......................................................... 09

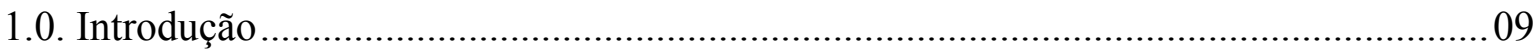

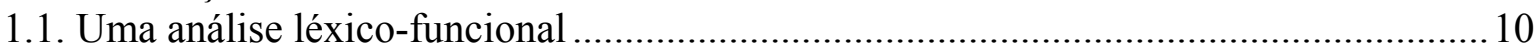

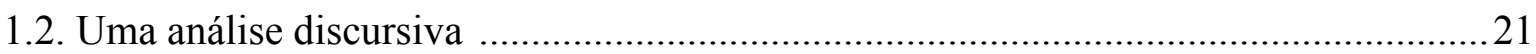

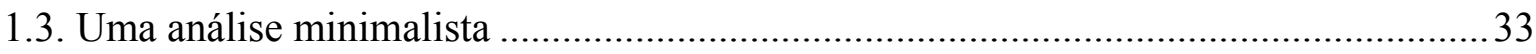

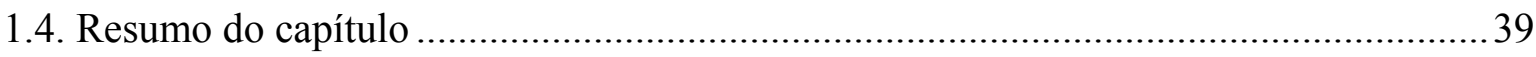

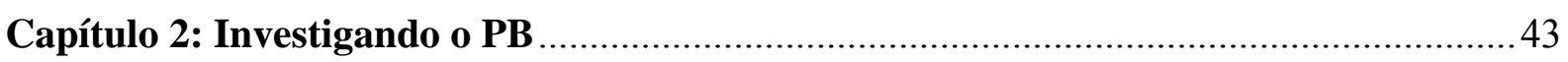

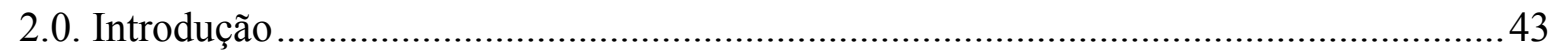

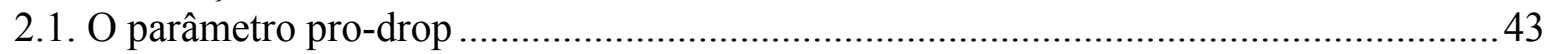

2.2. A atribuição de Caso nominativo ao sujeito.............................................................. 48

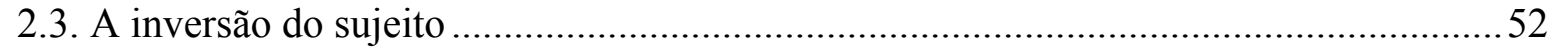

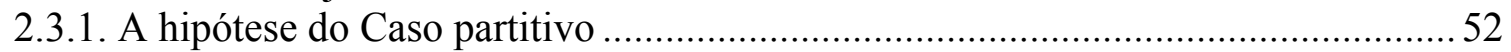

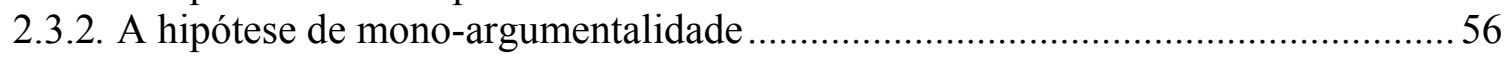

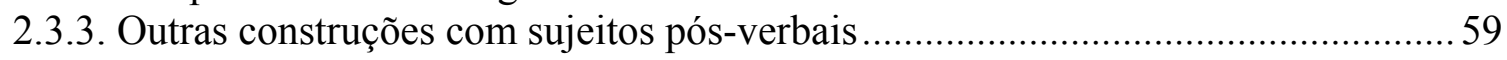

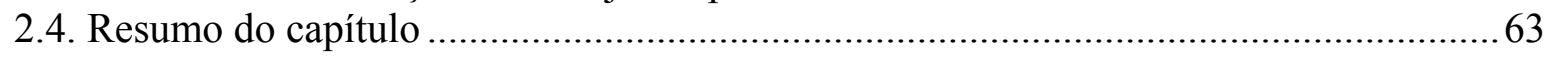

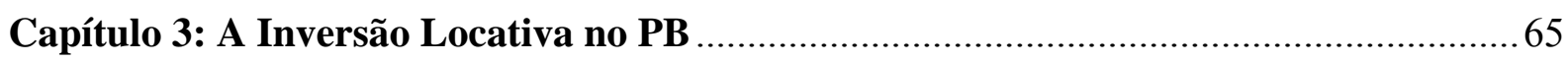

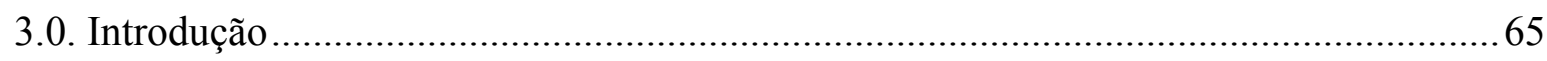

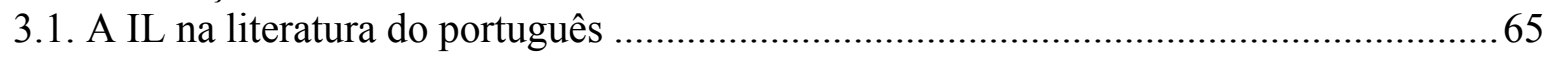

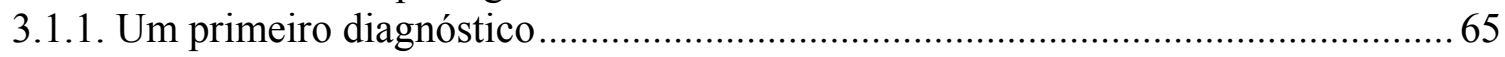

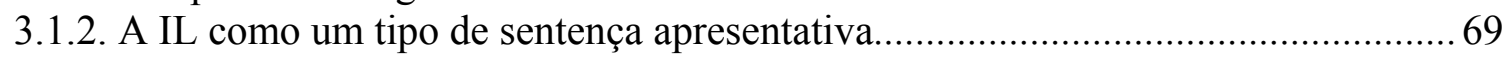

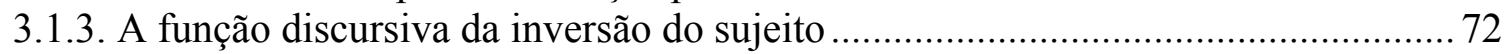

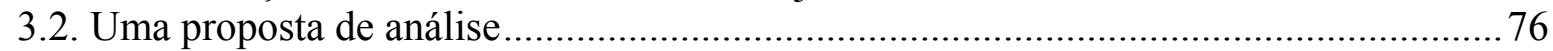

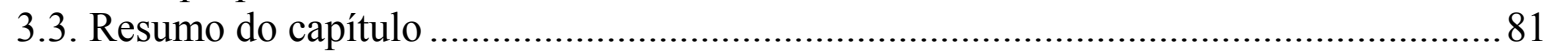

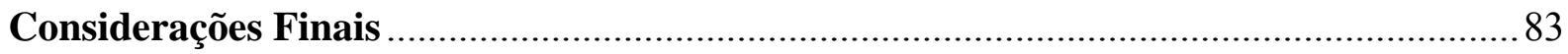

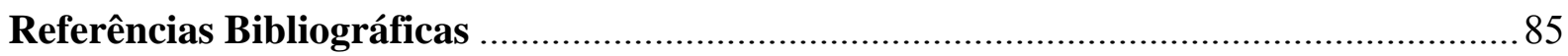




\section{Introdução}

Esta dissertação tem como objetivo descrever o fenômeno da inversão locativa (IL) no Português Brasileiro (doravante PB) e estudar as particularidades que tornam esta construção diferente dos outros tipos de inversão. Na presente pesquisa analisamos as construções que envolvem as estruturas de IL sob a perspectiva da Teoria Gerativa em sua versão de Princípios e Parâmetros (Chomsky 1981, 1986).

A IL tem sido descrita por diversos pesquisadores, sob diferentes pontos de vista, como um fenômeno de inacusatividade e como um fenômeno discursivo em línguas como o inglês e o espanhol. Sua estrutura padrão é a ordem PP V DP, em que o PP é um locativo (LOC) e o DP é um argumento tema em posição pós-verbal. Exaustivamente estudado e descrito nessas línguas, a IL ainda é um fenômeno relativamente novo na literatura do PB.

Buscando alcançar a melhor forma de expor e analisar o fenômeno da IL no PB, dividimos a dissertação em quatro capítulos. No primeiro capítulo, apresentamos os principais estudos sobre a construção no inglês e no espanhol. Partimos de uma análise léxico-funcional em que Bresnan \& Kanerva (1989) e Bresnan (1994) postulam a Hipótese do Foco Apresentacional para explicar a função discursiva da construção. Em seguida, apresentamos a análise discursiva de Levin \& Rappaport Hovav (1995) que propõem a Hipótese do Verbo Informacionalmente Leve, atribuindo à construção uma função discursiva mais geral que a primeira. A última análise apresentada traz uma visão minimalista recente sobre a construção através da descrição de fenômenos que se interrelacionam - a IL, a topicalização de PPs e o EPP.

O segundo capítulo introduz alguns conceitos gerativistas e propostas teóricas da literatura do PB que serão essenciais para a análise da IL que propomos para essa língua. Para compreendermos esse fenômeno, é fundamental investigar onde se coloca o PB atualmente dentro do parâmetro do sujeito nulo, como se dá a atribuição de Caso nominativo ao sujeito e em que contextos ocorre a inversão nessa língua. Assim, fazemos uma breve revisão da literatura do $\mathrm{PB}$, partindo da Hipótese do Caso Partitivo, passando pela a Hipótese de Mono-Argumentalidade, até chegar nas sentenças com SUJs invertidos tanto com verbos mono-argumentais quanto com VTs, nas quais podemos observar que as sentenças com VTs e a ordem VS ocorrem em determinados contextos no PB. 
O terceiro capítulo tem o objetivo de propor uma descrição para a construção no PB. Partimos de um dos primeiros trabalhos sobre a IL, em que Barbosa (1989) nos oferece algumas intuições iniciais para uma análise do fenômeno. Em um trabalho mais recente, mostramos que Pilati (2002) descreve as construções de IL como um dos tipos de sentenças apresentativas. Relacionando a função discursiva das sentenças apresentativas à IL, mostramos que Quarezemin (2006) propõe que estas construções são motivadas por tal função discursiva pelo fato de seus SUJs serem interpretados como o FOC das sentenças. Em seguida, apresentamos uma proposta de análise para a IL, mostrando que há dois tipos de ILs - a IL propriamente dita e a IL discursiva.

O quarto e último capítulo apresenta as considerações finais desta pesquisa, apontando algumas semelhanças entre a construção da IL e as construções de topicalização sem preposição. Mais do que propor uma análise para a IL no PB, nosso objetivo é mostrar a importância de tal fenômeno num âmbito maior dos estudos da gramática do PB, considerando que a IL pode ser uma pista que caracterizaria o PB como uma língua de traço EPP. 


\section{Capítulo 1: O Fenômeno da Inversão Locativa}

\subsection{Introdução}

O programa gerativista (Chomsky 1981, 1986) postula que todos os níveis da gramática são representados por configurações estruturais do mesmo tipo, ligadas por operações de movimento sintático. Os princípios universais são descritos por níveis de representações estruturais. Cada nível corresponde a uma dimensão diferente da estrutura da gramática: o nível léxico-computacional, que é o nível mais semântico, o nível gramatical ou sintático, que é o nível das relações gramaticais e o nível discursivo, que é o nível da força elocucionária.

O primeiro nível caracteriza-se pela atribuição de papéis temáticos (ou papéis $\theta$ ) e pela seleção das categorias gramaticais, que correspondem aos núcleos lexicais em volta dos quais os constituintes se organizam para formar sentenças. Os papéis $\theta$ correspondem às funções semânticas dos participantes gramaticalmente expressos numa sentença, ou seja, dos DPs complementos ou adjuntos. Por sua vez, o segundo nível é o nível no qual as funções sintáticas são estabelecidas entre os constituintes da sentença, caracterizado pela atribuição de Casos. O terceiro nível é o nível mais funcional, onde se marcam as funções discursivas das sentenças. Cada nível tem suas próprias relações, caracterizando, por exemplo, a diferença entre sujeito temático (ou sujeito lógico - gerado em spec, VP), sujeito sintático (sujeito gramatical ou estrutural) e sujeito funcional.

A inversão locativa (IL) é particularmente um fenômeno revelador da arquitetura da Gramática Universal por não apresentar uma correspondência convencional dos seus constituintes com os níveis representacionais em relação às categorias gramaticais, aos papéis $\theta$ e às funções sintáticas (Bresnan 1994). Dentro dessa concepção, a construção da IL parece negar alguns pressupostos.

No que se segue, apresentamos a visão de diferentes lingüistas para o estudo da IL, visão esta que decorre de posturas teóricas particulares. A primeira seção apresenta as análises de Bresnan \& Kanerva (1989) e Bresnan (1994) sob a perspectiva da Gramática Léxico-Funcional. Em seguida, apresentamos o estudo de Levin \& Rappaport Hovav (1995) numa perspectiva gerativista. Por fim, a última seção traz dois trabalhos recentes de Kempchinsky $(2001,2002)$ sobre a construção da IL no inglês e no espanhol do ponto de vista da Gramática Gerativa, mas em sua versão minimalista. 


\subsection{Uma análise léxico-funcional}

Em um dos principais trabalhos da literatura sobre a IL, Bresnan e Kanerva (B\&K 1989) comparam a sintaxe do inglês à sintaxe do chicheŵa ${ }^{1}$, uma das línguas Bantu da África centro-oriental, esta tipologicamente distante daquela. Os autores mostram que o chicheŵa marca suas relações gramaticais através da sua rica morfologia, enquanto que o inglês marca muitas das suas relações gramaticais através de relações oblíquas. Como ponto de comparação entre as línguas, escolheram o fenômeno da IL, o qual revelaria as principais diferenças entre as duas sintaxes.

Ao mesmo tempo que esse trabalho sustenta a hipótese da Gramática Universal (GU), também contesta a arquitetura padrão da GU que incorpora a Tese da Uniformidade Categorial (Baker 1991, Speas 1990), a qual diz que as estruturas subjacentes das línguas deveriam ser o mais semelhante possível para dar conta do fato de que qualquer língua pode ser aprendida por qualquer indivíduo sem muito treino (Baker 1991 apud Bresnan 1994). Assim, os autores questionam as configurações estruturais que representam os níveis da gramática tais como postula o modelo gerativista $(1981,1986)$ pois todos os níveis (a estrutura temática, as funções sintáticas e as funções discursivas) são representados da mesma forma, através de uma estrutura sentencial XP (VP, IP, CP, etc).

Para eles, as estruturas temática, categorial e funcional são estruturas paralelas, mas de caráter formal muito diferentes um do outro. Suas representações podem até ser estipuladas, mas formalmente são independentes na organização da gramática e essa independência pode ser atestada quando se analisa a construção da IL. Nesse sentido, afirmam que sua pesquisa foge de uma visão convencional gerativista.

Bresnan (1994), partindo de B\&K (1989), faz um estudo mais refinado e atualizado do fenômeno e vai além na discussão. Afirma que a IL é um fenômeno revelador da arquitetura da GU pois não apresenta a correspondência canônica esperada entre as categorias gramaticais, os papéis $\theta$ e as funções sintáticas. A autora argumenta que, nas ILs no inglês, não há sujeito estrutural (ou sujeito gramatical), o sujeito lógico é um objeto focado e o sujeito funcional é um complemento oblíquo PP que não mostra propriedades morfológicas ou estruturais de sujeito.

\footnotetext{
${ }^{1}$ Por desconhecermos a tradução para essa língua no português, manteremos a denominação chicheŵa, que foi usada no inglês.
} 
Nos dois trabalhos, o termo locativo foi usado para agrupar qualquer tipo de localização espacial, direções e suas extensões para domínios locativos abstratos e temporais. A construção da IL involve um locativo (LOC) anteposto ao verbo (V) e um sujeito (SUJ) NP posposto. As posições dos argumentos LOC e SUJ são invertidas sem haver alteração da estrutura semântica do V. Os exemplos (1a), (2a) e (3a) abaixo caracterizam a IL no inglês em contraste com (1b), (2b) e (3b), que seguem a ordem canônica da língua (Bresnan 1994: 75):

(1) a. In the corner was a lamp.

No canto estava um abajur. ${ }^{2}$

b. A lamp was in the corner.

(2) a. Among the guests was sitting my friend Rose.

Entre os convidados estava sentada minha amiga Rosa.

b. My friend Rose was sitting among the guests.

(3) a. Back to the village came the tax collector.

De volta à vila veio o coletor de impostos.

b. The tax collector came back to the village.

B\&K (1989) observaram que a literatura sobre a IL estava cheia de propostas conflitantes nas quais o NP posposto ao verbo podia ser considerado um SUJ verdadeiro, um SUJ demoted ${ }^{3}$ ou um objeto (OBJ), e o LOC anteposto ao V podia ser considerado um tópico (TOP), um SUJ, um adjunto adverbial (AADV) ou um pseudo-SUJ. A literatura sobre a construção no inglês continuou indo longe nas divergências: o NP invertido é tratado como um OBJ de V inacusativo por Coopmans (1989) e Levin (1991); como SUJ por Rochemont \& Culicover (1990); como SUJ complemento de small clause por Hoekstra \& Mulder (1990); e como SUJ demoted por Levin \& Rappaport Hovav (1992).

Algumas afirmações podem ser feitas a partir da observação dos exemplos anteriores. As posições dos argumentos foram invertidas sem alterar a estrutura semântica

\footnotetext{
${ }^{2}$ As traduções serão feitas "ao pé da letra", não apresentando, portanto, nenhum juízo de gramaticalidade.

${ }^{3}$ Demoted subject é um sujeito que perde as suas propriedades típicas de sujeito.
} 
dos verbos. Além disso, todos os verbos nas ILs (be ${ }^{4}$, sit e come) selecionam LOCs como complementos. Por fim, a IL parece ocorrer somente com verbos intransitivos (VIs).

De fato, a intransitividade verbal mostra-se como uma restrição para a ocorrência da construção. A presença de verbos transitivos (VTs) inibe a inversão, como pode ser visto nos exemplos seguintes (Bresnan, 1994: 77):

(4) a. My friend Rose seated my mother among the guests of honor.

Minha amiga Rosa sentou minha mãe entre os convidados de honra.

b. * Among the guests of honor seated my mother my friend Rose.

c. * Among the guests of honor seated my friend Rose my mother.

(5) a. A lucky hiker can find the reclusive lyrebird in this rainforest.

Um sortudo aventureiro ${ }^{5}$ pode encontrar o recluso pássaro australiano nesta floresta tropical.

b. ${ }^{*}$ In this rainforest can find the reclusive lyrebird a lucky hiker.

c. * In this rainforest can find a lucky hiker the reclusive lyrebird.

No entanto, é possível encontrar a construção com alguns VTs passivizados quando o agente da passiva não é realizado, como mostram os exemplos (6)-(8) (Bresnan 1994: 78):

(6) a. My mother was seated among the guests of honor.

Minha mãe foi sentada entre os convidados de honra.

b. Among the guests of honor was seated my mother.

(7) a. The reclusive lyrebird can be found in this rainforest.

O recluso pássaro australiano pode ser encontrado nesta floresta tropical.

b. In this rainforest can be found the reclusive lyrebird.

\footnotetext{
${ }^{4} \mathrm{O}$ inglês também possui inversão não-locativa que é restrita ao verbo be (cf. Bresnan 1994: 75).

${ }^{5}$ Hiker é a pessoa que se aventura caminhando por trilhas em matas fechadas, florestas e montanhas por lazer. Por não haver um termo específico para a palavra no português, hiker foi traduzido pelo termo genérico aventureiro.
} 
(8) a. A tarte Tatin has been placed on the table.

Uma torta foi colocada na mesa.

b. On the table has been placed a tarte Tatin.

Uma outra contradição interessante é o fato de que, apesar do fenômeno da IL ocorrer quase que exclusivamente com VIs, não ocorre com todos os verbos dessa classe. Os VIs podem ser divididos entre aqueles que permitem a construção e aqueles que não a permitem. Os exemplos a seguir ilustram tal divisão (Bresnan 1994: 78):

(9) a. Among the guests was sitting my friend Rose.

Entre os convidados estava sentada minha amiga Rosa.

b. * Among the guests was knitting my friend Rose.

Entre os convidados estava tricotando minha amiga Rosa.

(10) a. Onto the ground had fallen a few leaves.

No chão tinham caído poucas folhas.

b. * Onto the ground had spit a few sailors.

No chão tinham cuspido poucos marinheiros.

(11) a. Into the hole jumped the rabbit.

Para o buraco pulou o coelho.

b. * Into the hole excreted the rabbit.

No buraco excretou o coelho.

(12) a. Toward me lurched a drunk.

Na minha direção cambaleava um bêbado.

b. * Toward me looked a drunk.

Na minha direção olhava um bêbado.

(13) a. On the corner was standing a woman.

$\mathrm{Na}$ esquina estava (de pé) uma mulher. 
b. * On the corner was drinking a woman.

$\mathrm{Na}$ esquina estava bebendo uma mulher.

Com relação à estrutura de argumentos, Bresnan (1994) sugere uma hipótese de que a IL só pode ocorrer no caso de o SUJ ser interpretado como o tema da localização, da mudança de localização ou de direção expressa pelo complemento LOC. Nesse caso, os verbos be, sit e come satisfazem a caracterização de terem sujeitos cujos papéis $\theta$ são os temas da localização predicada.

Em contraste, os VTs como seat, find e place predicam localizações de seus OBJs, não de seus SUJs. Quando os mesmos VTs são passivizados, no entanto, o agente é suprimido e o SUJ recebe o papel $\theta$ tema, tornando possível a IL. Por outro lado, verbos como knit, spit, excrete, look e drink não predicam localização de seus SUJs. Se um LOC ocorre com esses verbos, ou é um AADV descrevendo a localização de todo o evento ou predica a localização de um complemento não-SUJ.

Tais evidências mostram que a estrutura de argumentos $<$ tema - locativo $>$ está associada à IL. B\&K (1989) observaram que o papel $\theta$ tema, assim como outros papéis $\theta$ passivos, universalmente alternam entre o SUJ e o OBJ. O tema é o papel $\theta$ do OBJ sintático de um VT e é também o papel $\theta$ do SUJ sintático de um VT na voz passiva. Já VIs (como be, sit e come) têm o tema como papel $\theta$ de seus SUJs sintáticos, mas permitem que apareçam na posição pós-verbal de OBJ nas ILs. Esta é, na verdade, a Hipótese Inacusativa.

A pesquisadora (1994) considera essa hipótese insuficiente e apresenta uma análise alternativa para a IL através de uma análise léxico-funcional, que ficou conhecida como a Hipótese do Foco Apresentacional. Na IL, o argumento tema é um foco (FOC) relativo ao argumento LOC. O NP tema é introduzido ou reintroduzido no contexto pelo LOC que encabeça a sentença.

Um contexto é naturalmente expresso como um LOC e o referente, como um tema. Isso impõe uma seleção natural da estrutura de argumentos $<$ tema - locativo $>$. Os verbos que possuem tal grade argumental são geralmente verbos de localização ou de movimento. Como o papel $\theta$ tema pode ser o papel $\theta$ tanto do SUJ como do OBJ, a hipótese de Bresnan considera o LOC o papel semântico do SUJ, para que este possa ser, de fato, interpretado como o argumento [+ TOP]. Nessas condições, o tema é realizado como um OBJ e esta é a 
função sintática [+ FOC] por excelência. Um exemplo de FOC apresentacional está reproduzido abaixo (Bresnan 1994: 85):

(14) A: I'm looking for my friend Rose.

Eu estou procurando pela minha amiga Rosa.

B: \# Among the guests of honor was sitting Rose.

Entre os convidados de honra estava sentada a Rosa.

$\mathrm{C}$ : Rose was sitting among the guests of honor.

A Rosa estava sentada entre os convidados de honra.

A resposta B é estranha porque parece que depende que um contexto seja estabelecido, incluindo convidados de honra, o que A não prevê, e porque Rosa, tendo sido mencionada em $\mathrm{A}$, não pode ser reintroduzida naturalmente no contexto em $\mathrm{B}$. A forma não-invertida $\mathrm{C}$ é a resposta mais natural.

Como conseqüência de tal estrutura de argumentos, $<$ tema - locativo $>$, a análise prevê que o PP LOC seja considerado SUJ nas ILs do inglês. Para a autora, o argumento PP pré-verbal é um SUJ em um nível de representação mais abstrato, especificamente, na estrutura- ${ }^{6}$ da Gramática Léxico-Funcional, análoga em alguns aspectos à estrutura-S da Teoria de Regência e Ligação (doravante GB). A análise considera, portanto, que o PP é um SUJ funcional que acaba sendo topicalizado em estrutura-c.

Em geral, PPs não podem aparecer em posições de SUJ e OBJ. Embora isso não aconteça, podem ser interpretados como preenchedores dessas posições de duas maneiras: por extraposição e por topicalização. As sentenças em (15) ilustram exemplos de extraposição (Bresnan 1994: 106):

(15) a. It makes me happy in San Jose. (pro) $)^{7}$ Faz-me feliz em São José.

\footnotetext{
${ }^{6}$ A Gramática Léxico-Funcional postula a existência de três níveis configuracionais: a estrutura-a (estrutura argumental), nível em que se estabelece o mapeamento entre os papéis $\theta$ e as funções sintáticas; a estrutura-f (estrutura funcional), nível em que se estabelece o mapeamento entre as funções sintáticas e as funções discursivas; e a estrutura-c (estrutura categorial), nível em que ocorre o mapeamento entre as funções sintáticas e suas categorias (Kac 1978, Sadock 1991, Jackendoff 1993, Andrews \& Manning 1993).

${ }^{7}$ As expressões entre parênteses foram inseridas nas traduções para deixar evidente a extraposição do PP [in San Jose] que está relacionado às posições de SUJ e OBJ, as quais um PP não pode ocupar diretamente.
} 
b. I like it in San Jose.

Eu gosto (de lá) em São José.

c. I expect it to please me in San Jose.

Eu espero (ela) agradar-me em São José.

A segunda maneira de um PP ser interpretado como preenchedor da posição de SUJ ou de um OD é por topicalização (Bresnan 1994: 106):

(16) a. On this wall I expect will be hung a picture of Leonard Pabbs.

Nesta parede eu espero seja pendurado um quadro de Leonard Pabbs.

b. In San Jose lived a woman.

Em São José morava uma mulher.

Mais do que envolver movimento de um constituinte de uma posição para outra, a topicalização envolve a identificação de duas funções discursivas: TOP e FOC, as quais podem ser exercidas tanto por um SUJ como por um OBJ.

A análise do SUJ PP topicalizado explica as propriedades mistas do LOC na construção. A maior parte dos verbos invertidos não faz a concordância padrão esperada com o SUJ porque PPs não possuem marcas morfológicas de número como os NPs. Conseqüentemente, os verbos concordam com o NP pós-verbal (Collins 1997), contrariando a hipótese. ${ }^{8}$ Daí surgem as divergências em considerar o PP LOC como SUJ ou não.

A concordância mostra-se, na verdade, como um dos principais argumentos contra a análise. Enquanto no chicheŵa o $\mathrm{V}$ concorda obrigatoriamente com o argumento locativo, no inglês, o V concorda com o argumento tema invertido (Bresnan 1994: 95):

(17) a. In the swamp was/*were found a child.

No pântano foi/ * foram encontrada uma criança.

\footnotetext{
8 * Down the hills roll John. (Collins 1997: 28)

Montanha abaixo rola o João.

Collins aponta que essa sentença só poderia ser gramatical se o V concordasse com o NP pós-verbal: Down the hill rolls John.
} 
b. In the swamp were/ *was found two children.

No pântano foram/*foi encontradas duas crianças.

Por outro lado, a primeira evidência para o status de SUJ do PP vem do efeito thattrace. Proposto por Chomsky \& Lasnik (1977), o filtro that-trace impede o movimento do SUJ por cima de um complementizador lexicalmente preenchido. Bresnan mostra que a extração do PP pré-verbal, na construção, comporta-se como a extração de SUJs com relação a esse efeito, mesmo que a extração de PPs internos a VP não lide com o efeito normalmente. Este está presente somente quando o PP é extraído de uma IL, como em (18), não quando é extraído da ordem canônica, como em (19). Tal contraste é ilustrado nos exemplos a seguir (Bresnan 1994: 97):

(18) a. It's in these villages that we all believe can be found the best examples of this cuisine.

É nestas vilas que todos nós acreditamos podem ser encontrados os melhores exemplos desta culinária.

b. * It's in these villages that we all believe that can be found the best examples of this cuisine.

É nestas vilas que todos nós acreditamos que _ podem ser encontrados os melhores exemplos desta culinária.

(19) a. It's in these villages that we all believe the finest examples of this cuisine can be found

É nestas vilas que todos nós acreditamos os mais finos exemplos desta culinária podem ser encontrados

b. It's in these villages that we all believe that the finest examples of this cuisine can be found

É nestas vilas que todos nós acreditamos que os mais finos exemplos desta culinária podem ser encontrados

O primeiro par de sentenças mostra a extração de um PP de uma sentença encaixada com IL. Já o segundo par mostra a extração do PP de uma sentença encaixada 
em sua ordem canônica. Esse comportamento sugere que o PP é um SUJ, já que a extração de outras posições internas ao VP não estimula o efeito.

Uma outra evidência de que o PP LOC é um SUJ vem da interação da construção com alçamento. Quando a IL está encaixada a um V de alçamento, o PP pré-verbal é alçado para se tornar o SUJ do V matriz (Bresnan 1994: 96):

(20) On thal hill appears to be located a cathedral. Naquele morro parece estar localizada uma catedral.

(21) In these villages are likely to be found the best examples of this cuisine. Nestas vilas é provável serem encontrados os melhores exemplos desta culinária.

(22) On this wall is likely to be hung a portrait of our founder. (Bresnan 1994: 108) Nesta parede é provável ser pendurado um retrato do nosso fundador.

Como ilustram os exemplos, a interação da IL com alçamento sugere que o PP pré-verbal é um SUJ.

As evidências descritas acima foram usadas pela autora para defender parte de sua tese de que, no fenômeno da IL no inglês, o SUJ funcional da construção é um oblíquo PP. Tais evidências constituem os principais argumentos para a análise que denominou como a Hipótese do Sujeito Locativo. Na tentativa de comprovar a outra parte de sua tese - mostrar que não há SUJ estrutural na construção e que, portanto, o SUJ lógico é um OBJ focado - , Bresnan também desenvolve a Hipótese do Sujeito Tema.

A hipótese afirma que o LOC é o SUJ gramatical em chicheŵa enquanto que, no inglês, o argumento tema invertido é apenas o SUJ lógico da IL. Embora o NP tema possa ser considerado o SUJ lógico ou temático, este não pode ser o SUJ gramatical, apesar de estabelecer concordância com o V. O primeiro argumento em favor dessa análise é baseado em tag questions do inglês.

Em tag questions, uma declaração é seguida de uma pergunta tag, que consiste de um $\mathrm{V}$ auxiliar e de um pronome. A pergunta tag é uma pergunta reduzida, a qual tem a função de confirmar a declaração explicitada. O pronome da pergunta tag deve conter os 
traços do SUJ sintático expresso na declaração, como mostram os exemplos seguintes (Bresnan 1994: 97):

(23) a. Mary fooled John, didn't she/ *he?

A Maria enganou o João, não enganou (ela/ *ele)?

b. John was fooled by Mary, wasn't he/ *she?

O João foi enganado pela Maria, não foi (ele/ *she)?

Segundo a autora, é difícil combinar question tags com IL. No entanto, Bresnan cita um exemplo possível criado por Bowers (1976) para argumentar que o NP pós-verbal não pode ser um SUJ gramatical na construção em questão:

(24) In the garden is a beautiful statue, isn't there? (Bowers 1976 apud Bresnan 1994: 97)

No jardim está uma estátua linda, não há?

Em (24), qualquer que seja o SUJ, seja ele o PP LOC ou o NP tema, este não estabelece uma "concordância" com o pronome there (que é um pronome expletivo) da pergunta tag. Isso demonstra que o NP pós-verbal não é sempre um SUJ gramatical na IL.

Um outro fator que distingue SUJs de não-SUJs em inglês é a restrição de paralelismo para a extração de constituintes coordenados. As sentenças em (25)-(26) ilustram tal fenômeno (Bresnan 1994: 98):

(25) a. She's someone that loves cooking and hates jogging. (SUBJ-SUBJ)

Ela é alguém que ama cozinhar e detesta fazer cooper. (SUJ-SUJ)

b. She's someone that cooking amuses and jogging bores (NONSUBJ-NONSUBJ)

Ela é alguém que cozinhar agrada e fazer cooper entedia . (não-SUJ - não-SUJ)

(26) a. *She's someone that cooking amuses and hates jogging. (NONSUBJ-SUBJ)

Ela é alguém que cozinhar agrada e detesta fazer cooper. (não-SUJ - SUJ)

b. She's someone that cooking amuses and I expect will hate jogging. (NONSUBJ-EMBEDDED SUBJ)

Ela é alguém que cozinhar agrada e eu espero detestará fazer cooper. (não-SUJ - SUJ da encaixada) 
Com relação à extração de SUJs, os exemplos demonstram que as lacunas de SUJ de constituintes coordenados não podem ocorrer com nenhum outro tipo de lacuna de consituinte coordenado. Isso explica a agramaticalidade de (26a).

Bresnan observa que a função discursiva da IL torna esse fenômeno difícil de ser manipulado com encaixamento, coordenação e extrações. Ainda assim, a autora diz que é possível construir exemplos aceitáveis nos quais as ILs estão encaixadas dentro de constituintes coordenados que são unidos por relativização. Bresnan reconhece que, quando isso é feito, os julgamentos de gramaticalidade tornam-se "delicados", mas consegue sustentar que os LOCs invertidos mostram o mesmo comportamento da extração de SUJs (Bresnan 1994: 98):

(27) a. That's the old graveyard, in which is buried a pirate and is likely to be buried a treasure. (SUBJ-SUBJ)

Aquele é o velho túmulo, no qual está enterrado um pirata e é provável ser enterrado um tesouro. (SUJ-SUJ)

b. That's the old graveyard, in which workers are digging and a treasure is likely to be buried (NONSUBJ-NONSUBJ)

Aquele é o velho túmulo, no qual trabalhadores estão cavando e um tesouro é provável ser enterrado . (não-SUJ - não-SUJ)

(28) a. ?? That's the old graveyard, in which workers are digging and is likely to be buried a treasure. (NONSUBJ-SUBJ)

Aquele é o velho túmulo, no qual trabalhadores estão cavando e é provável ser enterrado um tesouro. (não-SUJ - SUJ)

b. That's the old graveyard, in which workers are digging and they say is buried a treasure. (NONSUBJ- EMBEDDED SUBJ)

Aquele é o velho túmulo, no qual trabalhadores estão cavando e eles dizem está enterrado um tesouro.

Bresnan (1994) conclui que a Hipótese do Sujeito Tema não consegue explicar as diferenças existentes entre as ILs no inglês e no chicheŵa, nem o alçamento dos LOCs 
invertidos em ambas as línguas. As evidências sintáticas para o inglês - alçamento de SUJ, extrações paralelas de constituintes coordenados e tag questions - são suficientes para mostrar que o tema NP não é um SUJ estrutural na IL. Resta-lhe, assim, a função de SUJ lógico que, para satisfazer a estrutura de argumentos $<$ locativo - tema $>$, deverá ser um OBJ, tornando-se um FOC em estrutura-c.

\subsection{Uma análise discursiva}

Com o objetivo de explicar os vários fenômenos de inacusatividade, Levin \& Rappaport Hovav (L\&RH 1995) adotaram a definição de Perlmutter (1978) para o V inacusativo: $\mathrm{V}$ que seleciona um argumento interno, mas não, um argumento externo. Sob tal definição, os verbos inacusativos são idênticos aos VTs passivizados em termos configuracionais de estrutura-D, os quais também selecionam argumento interno, mas não, externo.

A Hipótese Inacusativa, formulada primeiramente por Perlmutter (1978) dentro do contexto da Gramática Relacional e, posteriormente, adotada por Burzio (1986) dentro da GB (Chomsky 1986), é uma hipótese sintática que afirma haver duas classes de VIs - os verbos inacusativos e os inergativos - cada uma associada a uma configuração sintática subjacente distinta. Um V inergativo, em estrutura-D, seleciona um SUJ como seu argumento, enquanto um $\mathrm{V}$ inacusativo seleciona um OBJ, que pode ser sentencial ou um DP, como seu argumento, sendo que este, embora gerado em posição de OBJ, não recebe Caso acusativo. Dessa forma, suas configurações encontram-se esquematizadas a seguir (L\&RH 1995):

\begin{tabular}{|l|}
\hline Verbo Inergativo: DP [vp V] \\
Verbo Inacusativo: __ _ [ ${ }_{\mathrm{vp}} \mathrm{V}$ DP/CP]
\end{tabular}

Segundo Burzio (1986), se um V não atribui papel $\theta$ a seu argumento externo, também não atribui Caso acusativo a seu argumento interno.

L\&RH observaram que a IL foi estudada como um caso de configuração sintática inacusativa por muitos autores, entre eles, L. Levin 1986, Coopmans 1989 e Hoekstra \& Mulder 1990. Duas evidências geralmente aparecem nos argumentos que embasam o status 
dessa análise: a presença de um determinado grupo de verbos - os VIs - e a sintaxe inacusativa na construção. No entanto, as autoras apontam problemas nessa caracterização inicial da IL como um fenômeno de inacusatividade pois somente uma subclasse coerente semanticamente de verbos inacusativos está representada na construção. Além disso, certos verbos inergativos também aparecem na IL.

Segundo as pesquisadoras, o nome dado a esta construção - inversão locativa reflete duas de suas propriedades (1995: 218):

i. é caracterizada por uma ordem dos constituintes não-canônica - PP V NP que parece ser o resultado de uma troca de posições entre o NP e o PP na ordem canônica NP V PP;

ii. possui um PP tipicamente LOC ou um PP direcional em posição préverbal. É desse LOC que sai o nome da construção.

No entanto, a construção tem uma terceira e talvez a mais importante de todas as propriedades que não está implícita na sua denominação:

iii. Com raras exceções, o verbo deve ser um VI.

Essa restrição combinada com a observação de que nem todos os VIs são encontrados na construção é que leva à investigação se a IL é um possível fenômeno de inacusatividade.

No entanto, como explicar a presença de verbos inergativos na IL? Essa é a grande questão que intriga as autoras. Uma possibilidade seria simplesmente negar que a construção é um fenômeno de inacusatividade e achar uma outra explicação para as suas propriedades distribucionais. Uma segunda possibilidade seria sugerir que os verbos inergativos encontrados na IL tenham dois comportamentos relacionados, um compatível com a análise inacusativa, um compatível com a análise inergativa.

L\&RH, inicialmente, assumem a primeira posição. As autoras argumentam que a construção da IL não é um fenômeno de inacusatividade, e sim, que não é um fenômeno restrito somente a verbos inacusativos. Atribuem suas propriedades inacusativas distribucionais ao fato de que essa construção está associada a uma função particular discursiva, a qual favorece certas classes semânticas de verbos. 
Um grupo de verbos inacusativos mostra que esses verbos desempenham tal função discursiva na construção, assim como um certo grupo de VTs passivizados. Além disso, em circunstâncias apropriadas, alguns verbos inergativos também são compatíveis com tal função discursiva. Assim, as autoras sugerem que as propriedades que constituem a IL são propriedades de "inacusatividade superficial” nas línguas em geral (1995: 217).

A construção é encontrada com VIs considerados membros prototípicos da classe inacusativa que incluem certos Vs de aparecimento, Vs de existência e Vs de movimento direcionado inerente, como ilustram os exemplos (29), (30) e (31), respectivamente (apud L\&RH 1995: 220-221 9):

(29) a. Over her shoulder appeared the head of Jenny's mother.

Sobre seu ombro apareceu a cabeça da mãe da Jenny.

b. From such optical tricks arise all the varities of romantic hallucination...

De tais truques ópticos crescem todas as variedades de alucinação romântica...

(30) a. At night, under the lights, (...) and the bus debarkation point, existed that stricken awareness of a dire event (...)

À noite, sob as luzes, (...) e o ponto de desembarque do ônibus, existia aquela aflita consciência de um mau presságio (...)

b. Here and there flourish groves of aged live oaks, (...)

Aqui e ali crescem arvoredos de envelhecidos vivos carvalhos, (...)

(31) a. ... out of the house came a tiny old lady and three or four enormous people ...

... para fora da casa vieram uma minúscula velha mulher e três ou quatro enormes pessoas...

b. ... with him had arrived hoards [sic] of workmen and carpenters...

... com ele tinham chegado estoques [sic] de trabalhadores e carpinteiros...

\footnotetext{
${ }^{9}$ Diferentemente de Bresnan (1994), L\&RH (1995) analisaram quase que exclusivamente dados de língua escrita, utilizando amplo e variado corpus da linguagem literária, o que dificultou a tradução dos exemplos. Os possíveis erros de tradução são de responsabilidade da autora desta dissertação.
} 
Outras classes semânticas de VIs encontrados nas ILs são Vs de modo de movimento e, menos freqüentes, Vs de emissão sonora quando selecionam complementos direcionais, como em (32) e (33) (apud L\&RH 1995: 221-222):

(32) a. Down the dusty Chisholm Trail into Abilene rode taciturn Spit Weaver, (...) Pela poeirenta Trilha Chisholm para Abilene cavalgava Spit Weaver, (...) b. Up the stairs bounded Senator Dickerson, wearing an outlandish Hawaiian shirt. Escadas acima saltava o Senador Dickerson, vestindo uma excêntrica camisa havaiana.

(33) Through the orchards rattled the field station's Ford pickup, bearing its two silent passengers. Pelos pomares rangia a pickup Ford da estação, carregando seus dois silenciosos passageiros.

Além dessas classes semânticas de VIs, a construção também é encontrada com VTs passivizados (apud L\&RH 1995: 222):

(34) a. From this trench were recoverd sacrificial burials and offerings dating to the final days of the Aztec empire.

Desta vala foram recolhidos restos mortais de sacrifícios e oferendas datando dos dias finais do império asteca.

b. On the house roof has been mounted a copper lightining rod (...)

No telhado da casa foi montado um pára-raios de cobre (...)

Embora a IL seja encontrada com verbos inacusativos prototípicos e VTs passivizados, nem todos VIs parecem ser compatíveis com a construção, como podemos ver nos exemplos (35)-(38) (L\&RH 1995: 222):

(35) a. Local residents shop at the supermarket on Main St.

Residentes locais compram no supermercado na Rua Principal.

b. * At the supermarket on Main St. shop local residents.

No supermercado na Rua Principal compram os residentes locais. 
(36) a. Many artists talk in the cafés of Paris.

Muitos artistas conversam nos restaurantes de Paris.

b. * In the cafés of Paris talk many artists.

Nos restaurantes de Paris conversam muitos artistas.

(37) a. Half a dozen newborn babies smile in the nursery.

Meia dúzia dos bebês recém-nascidos sorriem na maternidade.

b. * In the nursery smile half a dozen newborn babies.

Na maternidade sorriem meia dúzia dos bebês recém-nascidos.

(38) a. Many disgruntled people complain in government offices.

Muitas pessoas descontentes reclamam nos escritórios do governo.

b. * In government offices complain many disgruntled people.

Nos escritórios do governo reclamam muitas pessoas descontentes.

Como os exemplos sugerem, os VIs que não são encontrados na IL caem na classe semântica de verbos cujos membros são verbos inergativos. A maioria deles selecionam argumentos agentivos.

Finalmente, como também mostrou Bresnan (1994), VTs não ocorrem na construção, com exceção de alguns VTs passivizados (L\&RH 1995: 223):

(39) a. Archeologists recovered sacrificial burials from this trench.

Arqueólogos recolheram restos mortais de sacrifícios desta vala.

b. * From this trench recovered archeologists sacrificial burials.

c. * From this trench recovered sacrificial burials archeologists.

(40) a. An electrician mounted a copper lightning rod on the house roof.

Um eletricista montou um pára-raios de cobre no telhado da casa.

b. * On the house roof mounted an electrician a copper lightning rod.

c. * On the house roof mounted a copper lightning rod an electrician. 
Tais propriedades distribucionais da IL são as propriedades esperadas de um fenômeno de inacusatividade: VTs passivizados e verbos inacusativos apresentam um comportamento diferente de VTs e de verbos inergativos. Os primeiros distinguem-se dos últimos por selecionarem um argumento interno, mas não selecionarem um argumento externo.

Apesar disso, como observaram as autoras, nem todos verbos inacusativos podem ocorrer na IL. Em particular, verbos inacusativos de mudança de estado não são atestados na construção, como ilustram os exemplos em (41) (1995: 224):

(41) a. * On the top floor of the skyscraper broke many windows.

No último andar do arranha-céu quebraram muitas janelas.

b. * On the streets of Chicago melted a lot of snow.

Nas ruas de Chicago derreteu muita neve.

c. * On backyard clotheslines dried the weekly washing.

Nos varais dos fundos secaram as roupas da semana.

Por outro lado, curiosamente, alguns verbos encontrados na construção parecem ser verbos inergativos. Os exemplos abaixo envolvem vários tipos de Vs de atividade com SUJs animados, incluindo verbos que são considerados membros prototípicos da classe inergativa (apud L\&RH 1995: 224):

(42) a. On the third floor worked two young women called Maryanne Thomson and Ava Brent, (...)

No terceiro andar trabalhavam duas jovens mulheres chamadas Maryanne Thomson e Ava Brent, (...)

b. Behind the wheel lounged a man uniformed with distinct nautical flavour.

Atrás da roda descansava um homem uniformizado com uma distinta fragância náutica.

c. At one end, in crude bunks, slept Jed and Henry...

De um lado, no rude beliche, dormiam Jed e Henry...

A existência de verbos inergativos na IL coloca-se como um problema para a Hipótese da Inacusatividade. L\&RH apontam algumas possíveis soluções para esse 
problema. A primeira solução seria tratar os casos problemáticos de IL como excepcionais. No entanto, o fenômeno parece ser muito freqüente para que essa possibilidade seja viável. Outra solução seria propor que esses verbos inergativos permitem um segundo significado, o qual estaria associado a uma análise inacusativa como uma conseqüência da divisão da classe intransitiva.

L\&RH, entretanto, assumem uma terceira possibilidade, a qual nega a proposta de que a IL é um fenômeno de inacusatividade e propõe uma alternativa para as suas propriedades inacusativas. As autoras argumentam que a função discursiva da IL restringe o grupo de verbos que participam da construção. Tal função discursiva parte da Hipótese do Foco Apresentacional, proposto por Bresnan (1994) (cf. seção 1.1).

Como vimos, Bresnan (1994) propõe uma restrição em termos de papéis semânticos. Nesse sentido, a IL está disponível somente com verbos que selecionam argumentos cujos papéis $\theta$ são um tema e um LOC. Por outro lado, Bolinger (1977) e Penhallurick (1984) (apud L\&RH 1995), caracterizam o gupo de verbos que podem ocorrer na construção como Vs de existência e aparecimento. L\&RH notam que há algo em comum entre esta caracterização e a de Bresnan, já que Vs de existência e de aparecimento geralmente descrevem a existência e o aparecimento de um referente-tema em uma determinada localização. A restrição semântica observada para os Vs de existência e aparecimento tem sido associada à função discursiva da IL: a função do FOC apresentacional, que é usado para introduzir o referente do NP pós-verbal em um contexto.

A partir disso, L\&RH trazem uma discussão de Birner $(1992,1994)$ a respeito da função discursiva da construção da IL. A autora argumenta que chamar tal função discursiva de FOC “apresentacional” é de alguma forma muito forte (apud L\&RH 1995: 229). Afirma que o NP pós-verbal não precisa ser sempre informação nova, como esperado se sua função fosse puramente apresentacional. Birner propõe que a função discursiva de todas as inversões, incluindo a IL, é ligar a informação relativamente não-familiar ao contexto principal através da informação que é colocada em posição inicial da sentença, a qual é relativamente familiar no discurso.

Na Hipótese do Foco Apresentacional, a posição do NP pós-verbal é atribuída à sua função discursiva. A posição de FOC é geralmente a posição de OBJ. No entanto, Birner atribui uma função discursiva mais geral à construção, a qual inclui a função do FOC apresentacional. A autora descreve o V na IL como informacionalmente leve (apud L\&RH 
1995: 230). A restrição para que o V seja informacionalmente leve no contexto significa que alguns tipos de verbos serão favorecidos na construção, inclusive alguns verbos inergativos.

L\&RH assumem que o requerimento para que o $\mathrm{V}$ seja informacionalmente leve explica a ausência de VTs na IL. Em uma sentença com um VT, a informação nova sobre o SUJ é dada pelo $\mathrm{V}$ e o OBJ juntos. Não é esperado que o SUJ de uma sentença desse tipo representará a informação menos familiar, como a função discursiva requer. Por outro lado, a prevalência de ILs com Vs de existência e aparecimento contrasta com a ausência de ILs com Vs de mudança de estado. Como mostram os exemplos em (41), os verbos melt, break e $d r y$ são verbos inacusativos de mudança de estado que não são encontrados na construção.

Segundo as autoras, verbos dessa classe não são informacionalmente leves porque predicam uma causa externa e, conseqüentemente, não-previsível, pois predicam a mudança de estado de seus argumentos. Assim, esses verbos contribuem com informação nova e, dessa forma, não são apropriados na construção. Entre os verbos inacusativos, somente os Vs de existência e aparecimento são inerentemente compatíveis com a função discursiva da IL.

Alguns Vs de emissão podem ocorrer na IL apenas nos sentidos de "aparecimento" ou "vir a existir", como os verbos ooze, strike e boom, conforme os exemplos dados pelas autoras (1995: 237-238):

(43) a. Oil oozed from the bottle.

Óleo vazou da garrafa.

b. The bottle oozed (oil).

A garrafa vazou (óleo).

(44) It just struck midnight.

Acabou de bater meia-noite.

(45) From the speaker booms the voice of Fox's ad sales head in Chicago. (apud L\&RH 1995: 238) Do alto-falante ressoa a voz do anunciante das promoções da Fox em Chicago. 
Neste caso, também podem ser incluídos os Vs de emissão sonora, como mostrou o exemplo (33), em que algo "aparece" em cena através do som que emite.

Com relação aos Vs de movimento direcionado inerente, há muitas evidências de que sejam verbos inacusativos. Para as autoras, a ocorrência desses verbos na construção não é justificada pela sua inacusatividade, mas por serem informacionalmente leves. L\&RH propõem que sejam encontrados somente quando descrevem "aparecimento" no contexto. Como exemplo, o verbo come pode selecionar um argumento tema. Por causa da sua orientação dêitica, esse verbo naturalmente pode ser usado para descrever o aparecimento de uma determinada entidade em uma cena, conforme visto em (31).

Da mesma maneira, nas ILs com Vs de modo de movimento, não só o NP pósverbal deve ser menos familiar que o NP complemento do PP pré-verbal, mas o PP deve ser "escolhido" para dar sentido de "aparecimento" na cena, como ilustram os exemplos a seguir (apud L\&RH 1995: 243):

(46) Into the room walked Sylvia Tucker, with Zahid walking behind her like a puppet.

Para dentro do quarto caminhou Sylvia Tucker, com Zahid andando atrás dela como um marionete.

(47) ... from out its hole crawled a gigantic monarch iguana, (...)

... de fora do seu buraco gatinhou uma gigantesca monarca iguana, (...)

(48) (...) when out of an open carriage at the gate, stepped Mrs. Duff-Scott (...)

(...) quando para fora de uma aberta carruagem no portão, pisou a Sra. Duff-Scott (...)

Embora esses verbos descrevam modos de movimento e, assim, possuírem um componente de significado que proveria informação não-previsível, quando aparecem no seu sentido de movimento direcionado, a interpretação de aparecimento associada à construção da IL serve para minimizar a contribuição do $\mathrm{V}$ e tornar a interpretação da IL compatível com sua função discursiva.

Dadas as restrições para a construção, somente alguns VTs passivizados são esperados na IL. Bresnan (1994) aponta que os casos de IL com VTs na voz passiva devem encontrar as mesmas restrições que os casos com VIs, isto é, somente aqueles que têm a 
estrutura de argumentos < tema - locativo > ocorrerão na construção. L\&RH, por sua vez, propõem que tal restrição já está contida na exigência de que o $\mathrm{V}$ seja informacionalmente leve no contexto. As autoras apresentam uma lista de subclasses semânticas dos VTs passivizados encontrados em seu corpus (cf. L\&RH 1995: 245-246). As subclasses desse tipo de $\mathrm{V}$ encontradas na voz passiva na IL podem ser descritas como classes de verbos que levam algo a "existir" ou "aparecer", como mostrou o exemplo (34).

L\&RH afirmam, portanto, que não há nenhuma razão sintática convincente para assumir uma análise inacusativa para a IL. A explicação em termos de função discursiva dá conta de explicar o fenômeno. Contudo, o que faz a IL com verbo inergativo satisfazer a função discursiva da construção?

Para que isso aconteça, o NP pós-verbal teria que ser menos familiar que o NP complemento do PP pré-verbal. Além disso, o V não poderia contribuir com informação mais nova que o NP invertido, isto é, teria que ser informacionalmente leve no contexto. De acordo com as autoras, o que explica o fato de ILs ocorrerem com verbos inergativos é que, nessas construções, o V e o NP pós-verbal são "mutuamente previsíveis" e, assim, permitem a função discursiva da IL (1995: 253).

As pesquisadoras sustentam que a leveza de informação pode ser satisfeita se a atividade ou o processo que o $\mathrm{V}$ descreve é uma característica da entidade predicada pelo $\mathrm{V}$, como mostram os exemplos em (49) e (50) (apud L\&RH 1995: 257):

(49) Inside swam fish from an iridescent spectrum of colors...

Dentro nadavam peixes de um luminoso espectro de cores...

(50) Above it flew a flock of butterflies, (...)

Acima dali voava um bando de borboletas, (...)

Em (49) o verbo swim não predica nenhuma informação nova sobre o NP [fish], já que swimming é um tipo de movimento característico da existência dos peixes. Dessa forma, o $\mathrm{V}$ está sendo usado simplesmente para caracterizar a "existência" de peixes coloridos naquele lugar. Do mesmo modo, o verbo fly não contribui com nenhuma informação nãofamiliar sobre o DP [a flock of butterflies]. Como flying é um movimento típico das borboletas, o V apenas predica sua "existência" no contexto. 
Assim, L\&RH propõem duas propriedades das ILs com verbos inergativos que comprovam sua proposta: os verbos inergativos encontrados na construção incluem aqueles que impõem restrições de seleção rigorosas sobre seus argumentos, como em (49) e (50), e mesmo aqueles inergativos que não fazem isso são encontrados nas ILs com um grupo restrito de argumentos, como os casos de (42) em que todos os argumentos NPs são seres animados e definidos.

Em seu trabalho, também, as autoras revêem o argumento que é usado para justificar a análise inacusativa em outros estudos. Tal argumento é construído de dois fatores:

i. a evidência de que o PP pré-verbal é um SUJ em algum nível de representação da gramática (Bresnan 1994);

ii. uma vez que isso é estabelecido, é possível argumentar que o NP pósverbal pode ser um OBJ em estrutura-D.

As pesquisadoras questionam o segundo fator, já que faz uso de uma postulação não mais universalmente aceita, dada a postulação da Hipótese do Sujeito Interno ao VP (ou Predicate-Internal Subject Hypothesis $(P I S H))^{10}$. Assim, o argumento como um todo perde sua força pois a PISH sugere que todo SUJ é gerado dentro de VP, não importando que tipo de $\mathrm{V}$ o selecionou, e depois se move para spec, IP para checar o EPP.

De acordo com essa hipótese, o argumento externo de VTs e de verbos inergativos originam-se em spec, $V P$, mas o argumento interno de um $\mathrm{V}$ inacusativo ainda se origina como irmão de $\mathrm{V}^{\mathrm{o}}$, isto é, na posição de OBJ. Sob tal análise, na IL com verbos inergativos, o argumento externo do $\mathrm{V}$ é gerado dentro de VP para que um PP complemento possa se mover para spec, IP sem violar o Critério $\theta$ e o Princípio de Projeção. Adotando-se a PISH, portanto, não há razão para que verbos inergativos sejam excluídos da IL.

Posteriormente, o argumento externo do $\mathrm{V}$ inergativo move-se para uma posição à direita do V, uma posição adjungida a VP, do mesmo tipo que foi postulada para o FOC.

\footnotetext{
${ }^{10}$ A idéia de que os SUJs são gerados dentro do VP foi proposta dentro da GB por vários autores, entre eles, Zagona (1982), Kitagawa (1986), Speas (1986), Contreras (1987), Kuroda (1988), Sportiche (1988) e os criadores do termo VP-Internal Subject Hypothesis, Koopman \& Sportiche (1991).
} 
As autoras assumem que esse movimento é necessário por causa da função discursiva da construção, como mostram na derivação em (51) (1995: 265):

(51) a. Estrutura-D: [IP $e$ [I, I [vP NP [V, V PP]]]]

b. Estrutura-S: $\left.\left[{ }_{I P} P_{i}\left[I_{j}, V_{j}+{ }_{v p}\left[v P t_{k}\left[v^{\prime} t_{j} t_{i}\right]\right] N_{k}\right]\right]\right]$

Mesmo em uma análise inacusativa da IL, L\&RH dizem que há discussões se o NP pós-verbal é, de fato, um $\mathrm{OBJ}$ em estrutura-S ou se ocupa alguma outra posição à direita da posição de OBJ, possivelmente como uma conseqüência da função discursiva da construção. Por este motivo, assumem que o NP pós-verbal não está na posição canônica de $\mathrm{OBJ}$, mas em uma posição mais à direita adjungida a VP, uma posição de foco, como demonstra a derivação em (52) (1995: 265):

(52) a. Estrutura-D: [IP $e$ [I, I [vp [v, V NP PP] $]]]$

b. Estrutura-S: [iP $\left.P P_{i}\left[\mathrm{r}, \mathrm{V}_{\mathrm{j}}+\mathrm{I}\left[\mathrm{vP}\left[\mathrm{vP}\left[\mathrm{v}, \mathrm{t}_{\mathrm{j}} \mathrm{t}_{\mathrm{k}} \mathrm{t}_{\mathrm{i}}\right]\right] \mathrm{NP}_{\mathrm{k}}\right]\right]\right]$

No entanto, tal análise apresenta um problema. Nessa posição, o NP pós-verbal não recebe Caso. Embora reconheçam o problema, as autoras não propõem nenhuma solução para resolvê-lo:

We do not set out exactly how the postverbal NP would receive Case here; since our goal is understanding the constraints on the verbs in locative inversion, we have explored the syntax of the construction only to the extent that it impinges on this issue. (1995: 268)

L\&RH mostram que não há outra evidência convincente para que o NP pós-verbal seja um OBJ. Se esse é o caso, não há razão para assumir que os SUJs de verbos inergativos nas ILs sejam qualquer outra coisa que não, o SUJ. Para dar conta de explicar o fenômeno da IL, atribuíram à construção uma função discursiva a qual só pode ser satisfeita com a presença de um $\mathrm{V}$ informacionalmente leve na construção. 


\subsection{Uma análise minimalista}

Nesta seção, apresentamos dois trabalhos de Kempchinsky $(2001,2002)$ a respeito dos fenômenos da IL e da topicalização no inglês e no espanhol. Em ambos artigos, a autora compara as duas línguas em termos das posições pré-verbais que os PPs podem ocupar nas sentenças, particularmente analisando fenômenos lingüísticos que se interrelacionam: a IL, a topicalização de PPs e o traço EPP.

Sua análise é apresentada sob uma postura teórica gerativista, especificamente em sua versão minimalista (Chomsky 1995, 1998). Por se tratar de uma visão mais avançada e desenvolvida da teoria que usaremos em nossa análise da IL para o PB (cf. capítulo 3), não entraremos nos detalhes das análises minimalistas realizadas pela autora, mas apenas apresentaremos as descrições dos fenômenos tais quais foram descritos sem questioná-las. Nossa intenção, neste capítulo, mais do que "analisar" os diversos estudos sobre o fenômeno da IL é apresentar os principais trabalhos a respeito da construção existentes na literatura em seus diferentes pontos de vista.

Segundo Kempchinsky (2002), as construções de IL em uma língua como o inglês, que não permite SUJs pós-verbais, são claramente distintas da topicalização de PPs, embora as duas construções compartilhem a mesma restrição discursiva de que os PPs invertidos representam a informação relativamente mais familiar no discurso. Seguindo Birner (1992, 1994), a autora aponta que o SUJ na IL no inglês, diferente do SUJ na topicalização de PPs, deve ser um FOC apresentacional, o que sugere movimento em algum ponto da derivação para a posição $s p e c, F o c P$.

Sintaticamente, a IL é restrita a VIs, incluindo VTs passivizados, embora não necessariamente a verbos inacusativos (L\&RH 1995). Além disso, o LOC pré-verbal PP ou adverbial deve ser um argumento, não um adjunto e possui um papel $\theta$ de localização ou direção. Finalmente, como SUJs, um PP pré-verbal na IL estimula o efeito that-trace (cf. seção 1.1). Com relação a suas restrições discursivas, a IL é muito comparável à topicalização. A informação do LOC PP, como os tópicos em geral, ou é saliente no contexto ou informação velha no discurso. Em contraste, o SUJ pós-verbal deve representar informação nova ou relativamente não-familiar com relação à informação representada pelo PP. 
A autora aponta que a construção também compartilha de uma importante característica sintática com a topicalização: em aqueles contextos nos quais a topicalização não é permitida, a IL também não é possível. Assim, o PP pré-verbal comporta-se sintaticamente em parte como um SUJ, em parte como um elemento topicalizado, mas discursivamente como um tópico "puro" (2001: 163).

Em Kempchinsky (2002), argumenta que as restrições sintáticas para o PP estar em posição pré-verbal no inglês vêm do fato de que, nessa língua, a IL é possível somente quando o SUJ DP e o PP estão no mesmo domínio mínimo, no qual tanto um quanto o outro está no alcance de atração do traço [+D] em T (Chomsky 1995). Assumindo que PPs LOCs são gerados como os complementos mais internos do V (Larson 1988), a estrutura configuracional do VP da sentença em (5a), reproduzida aqui em (53), é a que se segue em (54) (2002: 147):

(53) A lucky hiker can find the reclusive lyrebird in this rainforest.

Um sortudo aventureiro pode encontrar o recluso pássaro australiano nesta floresta tropical.

(54) [vp a lucky hiker [v' find [vp the reclusive lyrebird [ $v, t_{v}$ [pp in this rainforest]]]]]

Se o PP sobe para spec, TP para satisfazer o EPP, então o SUJ DP [a lucky hiker] deve checar seu caso no componente coberto, assim como o OBJ DP [the reclusive lyrebird]. De acordo com Kempchinsky, em Chomsky (1995), é sugerido que se um V tem dois argumentos que devem checar Caso, então, no mínimo, um deles deve checá-lo no componente aberto já que, de outra maneira, a relação de c-comando necessária entre os traços formais do SUJ e os traços formais do OBJ vão falhar na interface LF.

Dessa forma, se o DP e o PP estiverem no mesmo domínio mínimo, o PP pode "competir" com o argumento DP para satisfazer o EPP sob condições de localidade apropriadas. A restrição para a transitividade ocorre sob a condição de que a configuração transitiva tem um VP mais alto, a projeção do verbo light $\boldsymbol{v}$. Conseqüentemente, somente o SUJ pode se mover para spec, TP. Se o SUJ DP e o PP estão no mesmo nível, então estão equidistantes de T. De outra forma, o SUJ DP sempre estará mais perto e, assim, o PP nunca pode satisfazer o EPP. 
Para a autora, o requerimento de equidistância do argumento DP e do argumento PP na IL é o que levou Collins (1997) a estipular que a construção é possível somente com verbos inacusativos, apesar da existência de ILs com verbos inergativos. Este é o caso de verbos como work, os quais são inergativos por não projetarem o VP mais alto. Abaixo reproduzimos a sentença em (42a), mas aqui em sua ordem canônica (55), a qual pode ser representada pela estrutura em (56) (2001: 163):

(55) Two young women called Maryanne Thomson and Ava Brent worked on the third floor.

Duas jovens mulheres chamadas Maryanne Thomson e Ava Brent trabalhavam no terceiro andar.

(56) [vp [DP two young women] [v, worked [pp on the third floor]]]

Kempchinsky (2001), considerando os papéis $\theta$ como uma função de uma determinada configuração estrutural entre o V e seus argumentos (Bresnan 1994; cf. seção 1.1), assume que o SUJ de work não é um agente, mas um tema. Uma evidência de que o DP argumento em uma IL no inglês é estruturalmente um tema, ao invés de um agente, é a agramaticalidade de sentenças com interpretação agentiva nessas construções, como demonstrou a autora com o seguinte exemplo (2001: 164):

(56) * In this office works the President's personal secretary (in order) to take notes on everything which is discussed.

Neste escritório trabalha a secretária pessoal do presidente (com o objetivo de) para anotar tudo que é discutido.

Como vimos, a IL no inglês significa movimento de um LOC PP ou adverbial para a posição normalmente ocupada por um SUJ DP. O que diferencia esta construção da topicalização de PPs no inglês é a natureza da posição que o PP ocupa: uma posição A no caso da IL e uma posição A' no caso da topicalização. Se spec, TP, em uma determinada língua, for uma posição A', a diferença descrita entre as duas construções de fronteamento de PPs não é mais válida. Este é exatamente o caso do espanhol. 
A pesquisadora observa que as restrições sintáticas evidenciadas para o inglês estão aparentemente ausentes no espanhol. Os PPs pré-verbais podem aparecer com todas as classes de verbos e não são sensíveis à distinção argumento/ adjunto, como mostram os exemplos em (57) (2001: 165):

(57) a. En el cuarto entraron tres extranjeros.

No quarto entraram três estrangeiros.

b. En esta oficina trabajan los contables.

Neste escritório trabalham os contadores.

c. En esta sala escriben los estudiantes los exámenes.

Nesta sala escrevem os estudantes os exames.

d. En el rincón reía Juan.

$\mathrm{Na}$ esquina ria João.

Se a IL for definida estritamente como a preposição de um LOC na posição de SUJ (spec, TP), então a autora afirma que nem todos os exemplos acima são exemplos de IL. Alguns deles, como os exemplos em (57c, d) são casos de PPs topicalizados, equivalentes às sentenças em (58), mas com a inversão entre SUJ e V. Nestes casos, os PPs são AADVs dos verbos (2001: 165):

(58) a. En esta sala(,) los estudiantes escriben los exámenes.

Nesta sala(,) os estudantes escrevem os exames.

b. En el rincón(,) Juan reía.

$\mathrm{Na}$ esquina(,) João ria.

Como sugerem os exemplos, os PPs topicalizados geralmente compartilham as mesmas propriedades discursivas com os PPs das ILs, mas não apresentam as restrições sintáticas observadas para este fenômeno. Isso leva a uma análise de que a posição de SUJ pré-verbal no espanhol (spec, TP) é uma posição A', segundo a autora, uma análise defendida, sob diferentes perspectivas, por Goodall (1991), Ordóñez (1997) e Zubizarreta (1998). A grosso modo, podemos dizer que spec, TP é uma posição A' no espanhol por causa da sua rica concordância. 
Kempchinsky adota a análise de Agr de Ordóñez (1997) para o espanhol, a qual propõe que Agr e o DP lexical formam um DP complexo, como em (59), em que (59a) é o SUJ DP complexo e (59b) é um OBJ DP complexo (2001: 166):

(59) a. [DP [DP ellos] [D/Agr 3PL]] (cf. Ellos trabajan "Eles trabalham - 3PL.")

b. [DP [DP a ellos] [D/Agr los]] (cf. Yo los vi a ellos "Eu os vi.")

Se o núcleo D/Agr sozinho se move para T para satisfazer o EPP, então o DP lexical não se move e, por economia, não deve se mover, permanecendo in situ em spec, $v P$. Como um elemento dobrado do SUJ lexical, o núcleo também checa o Caso nominativo, já que D/ Agr é o núcleo do SUJ DP na configuração em (59a). Assim, o DP lexical não precisa se mover para spec, TP por nenhum motivo.

Em princípio, então, qualquer movimento de um XP para spec, TP no espanhol não será estimulado por traços interpretáveis (traços- $\Phi$ ) de T. No entanto, não deve ser o caso de que tal movimento seja livre, pelo contrário, deve ser estimulado por algum traço. $\mathrm{O}$ candidato lógico é algum traço-P(eriférico) geralmente associado com a periferia esquerda, como um TOP. Assim, pode-se dizer que constituintes pré-verbais topicalizados ocupam a posição spec, TP.

A autora nota que, a princípio, não há nenhuma razão para considerar que qualquer elemento ocupa spec, TP se o traço [+D] de T for checado por movimento de núcleo. Uma sentença como em (57d) pode ser representada pela estrutura em (60a) ou (60b), com TopP acima de TP (2001: 167):

(60) a. [TopP En el rincón TOP ${ }^{\circ}{ }_{\mathrm{TP}}\left[\mathrm{T}\right.$ reía] [vP Juan $\left.t_{\mathrm{VP}} \mathrm{t}_{\mathrm{PP}}\right]$ ]]

b. [TP En el rincón [ ${ }_{\mathrm{T}}$ reía] [VP Juan $\left.\left.\left.\mathrm{t}_{\mathrm{VP}} \mathrm{t}_{\mathrm{PP}}\right]\right]\right]$

Entretanto, princípios de economia favoreciam a segunda estrutura em lugar da primeira. Por essa análise, portanto, Kempchinsky mostra que não há nenhuma construção especial de IL no espanhol a qual seja distinta da topicalização de PPs e, por esse motivo, não há restrições sintáticas para classes de verbos e para o status do PP como complemento ou adjunto em posição inicial nas sentenças dessa língua. 
A pesquisadora analisa detalhadamente as propriedades semânticas e sintáticas de constituintes topicalizados para estabelecer algumas diferenças entre SUJs pré-verbais e TOPs. O TOP, como uma posição na periferia esquerda, tem um status variável de uma análise para outra: é tratado tanto como uma posição adjungida a alguma outra projeção ou como uma posição funcional distinta na periferia esquerda.

Segundo Casielles-Suárez (1999, apud Kempchinsky 2001), a variação nos tratamentos semânticos e sintáticos dos TOPs é devido à combinação equivocada de duas noções diferentes de TOP em uma só. Ambos os tipos de TOP não focalizam informações, mas diferem nas suas propriedades discursivas e sintáticas. Assim, denominou o primeiro tipo “Tópico \#1" (TOP \#1), o qual é restrito a um único elemento, está relacionado a alguma posição inicial da sentença, pode ser mas não é necessariamente informação velha no discurso e pode ser mas não é necessariamente realizado sem acento. Por sua vez, o segundo tipo, denominado "Tópico \#2" (TOP \#2), não é restrito a um único elemento, pode estar em posição inicial da sentença mas não necessariamente, é necessariamente informação velha no discurso e necessariamente realizado sem acento.

A autora propõe que os dois tipos de TOP pertencem a diferentes articulações entre TOP e FOC: o TOP \#1 co-ocorre com um FOC largo, enquanto o TOP \#2 co-ocorre necessariamente com um FOC estreito. Além disso, o FOC largo é relacionado a uma posição mais à direita na sentença e pode projetar, ao passo que o FOC estreito é marcado e não está em uma posição mais à direita na sentença, podendo estar in situ ou na periferia esquerda. Para Kempchinsky, essas ocorrências são a chave para a análise sintática dos TOPs no espanhol.

Que tipo de TOP seria um PP fronteado? Para responder a essa pergunta, Kempchinsky observa a questão da agramaticalidade dos TOPs nas sentenças em contextos “O que aconteceu?”. Os SUJs pré-verbais diferem-se claramente de elementos topicalizados, os quais são agramaticais em tais contextos, como vemos no contrate entre os exemplos (61) e (62):

(61) ¿Qué pasó? (2001: 168)

O que aconteceu?

a. \# En el bar pegó el camarero a um cliente.

No bar bateu o garçom em um cliente. 
b. \# Al suelo cayó la lámpara.

No solo caiu a lâmpada.

(62) ¿Qué pasó? (2001: 171)

$\mathrm{O}$ que aconteceu?

a. Ganó David el premio gordo de la lotería. (VSO)

Ganhou Davi o prêmio grande da loteria.

b. David ganó el premio gordo de la lotería. (SVO)

Davi ganhou o prêmio grande da loteria.

c. \# Ganó el premio gordo de la lotería David. (VOS)

Ganhou o prêmio grande da loteria Davi.

Em um contexto do tipo "O que aconteceu?", a resposta deve constituir um FOC largo, isto é, toda a sentença representa a informação nova. Conseqüentemente, o PP fronteado não pode se referir a uma informação já familiar no contexto, daí a agramaticalidade das sentenças em (61). Seguindo a definição de Casielles-Suárez (1999), um FOC estreito ocorre somente com um TOP\#2. Se consideramos que os PPs nos exemplos (61a, b) são TOPs, devido à sua agramaticalidade, então, serão TOPs do tipo \#2.

Para que as mesmas sentenças sejam consideradas gramaticais, os PPs invertidos devem ser interpretados como SUJs pré-verbais. Da mesma forma, os SUJs das sentenças (62a, b) fazem parte de um FOC largo que, por sua vez, co-ocorre com um TOP \#1. Se consideramos o SUJ um FOC estreito, a sentença não é uma boa resposta para o contexto, como mostra a agramaticalidade de (62c). A partir dos exemplos, portanto, podemos concluir que, no espanhol, todos os SUJs pré-verbais são TOPs do tipo \#1, enquanto elementos topicalizados são TOPs do tipo \#2.

\section{4. Resumo do capítulo}

Vimos, na primeira seção, que Bresnan \& Kanerva (1989) apresentam uma análise da construção da IL no inglês em uma visão que foge de uma análise tradicional gerativista. Segundo a autora (Bresnan 1994), a IL é um fenômeno que revela a arquitetura da GU por não apresentar as correspondências canônicas entre as suas relações 
gramaticais. Nesse sentido, argumenta que a IL não possui um SUJ estrutural, seu SUJ lógico é um OBJ focado e seu SUJ funcional é um complemento oblíquo PP que não exibe propriedades estruturais de SUJ.

Partindo de seu primeiro trabalho, a pesquisadora desenvolve uma análise alternativa para descrever a construção da IL, já que considera insuficiente a Hipótese Inacusativa, adotada por muitos outros autores anteriormente. Assim, Bresnan (1994) sugere que a IL tenha a seguinte estrutura argumental: < tema - locativo $>$. Como conseqüência, o PP LOC é considerado o SUJ da construção, podendo ser, assim, o elemento [+TOP]. Por sua vez, o NP tema é considerado um OBJ, o elemento [+FOC] por excelência.

Através de uma análise léxico-funcional, a autora propõe a Hipótese do Foco Apresentacional. Por essa hipótese, o argumento tema é um FOC introduzido ou reintroduzido na situação discursiva pelo argumento LOC que aparece em posição inicial na construção. Dessa forma, o PP invertido é analisado como um SUJ funcional que é topicalizado em estrutura-c.

Evidências de efeito that-trace, alçamento, tag questions e extrações paralelas de constituintes coordenados corroboram o fato de que não há um SUJ estrutural na construção e que, portanto, o NP pós-verbal só pode ser um SUJ lógico, mas que se torna um OBJ focado para dar conta da função discursiva da IL. Assim, resta ao PP LOC a função de SUJ funcional.

Assim como Bresnan (1994), Levin \& Rappaport Hovav (1995) também questionam os trabalhos que tratam a IL como um fenômeno de inacusatividade. Argumentam que a construção não ocorre com todos os verbos inacusativos, mas pode ocorrer também com determinados verbos inergativos, o que constitui um grande problema para a Hipótese da Inacusatividade.

Mostramos, então, na segunda seção, que L\&RH propõem uma análise alternativa para as propriedades inacusativas da construção. Para as autoras, a IL está associada a uma função discursiva que restringe o grupo de verbos que participam do fenômeno. A análise para tal função discursiva parte da Hipótese do Foco Apresentacional de Bresnan (1994).

Seguindo Birner (1992, 1994), atribuem à IL uma função discursiva mais geral, a qual inclui a do FOC apresentacional, de que o $\mathrm{V}$ na construção deve ser informacionalmente leve. Por meio dessa análise discursiva, explicam a ausência de VTs e 
a presença de certos verbos inergativos na IL. As pesquisadoras mostram que, em sentenças com VTs, estes verbos juntamente com o OBJ predicam alguma informação sobre o SUJ. Dessa forma, não é de se esperar que um SUJ, nesse tipo de sentença, representa a informação nova no contexto, contrariando a função discursiva do FOC apresentacional.

Com relação às ILs com verbos inergativos, L\&RH sugerem que o $\mathrm{V}$ e o NP posposto são "mutuamente previsíveis", ou seja, nessas construções, o V descreve uma atividade característica típica da entidade predicada. Assim, sustentam que os verbos inergativos impõem restrições de seleção rigorosas sobre seus argumentos para que os primeiros sejam compatíveis com sua função discursiva, isto é, sejam informacionalmente leves no contexto.

Além disso, para as autoras, é suficiente que o PP LOC seja um SUJ em algum ponto da derivação. No entanto, contestam o fato de que o NP pós-verbal deve ser considerado um OBJ em estrutura-D. Com a postulação da PISH, tal argumento perde sua força, já que a hipótese sugere que todo SUJ é gerado dentro de VP. Assim, assumem que o NP posposto é gerado como SUJ e, posteriormente, move-se para uma posição mais à direita adjungida a VP, uma posição de FOC. Embora estejam cientes de que, nessa posição, o NP não recebe Caso, afirmam que não há evidências convincentes para considerar o NP invertido um OBJ.

Finalmente, na terceira seção, vimos que as ILs são construções completamente diferentes da topicalização de PPs, ainda que ambas construções apresentem a mesma restrição discursiva de que o PP representa a informação pressuposta no contexto. Como nas análises anteriores, Kempchinsky $(2001,2002)$ assume a Hipótese do Foco Apresentacional para o SUJ na IL.

Sob uma perspectiva minimalista, a autora argumenta que o PP LOC só pode estar em posição pré-verbal quando o DP e o PP estiverem no mesmo domínio mínimo de atração de T para checar o EPP, respeitando, assim, as condições de localidade. Isto é exatamente o que explica a restrição para VTs na construção. Tal restrição existe porque um VT deve projetar um VP mais alto, a projeção vP. Desse modo, o SUJ DP sempre está mais perto de T que o PP, não permitindo, portanto, que este satisfaça o EPP. No caso de verbos inergativos, propõe que esses verbos não projetam o verbo light (vP), o que permitiria sua ocorrência na IL. 
Assim, Kempchinsky (2001) diferencia os dois fenômenos lingüísticos de acordo com as posições que o PP ocupa nessas construções no inglês. Enquanto na IL o PP ocupa uma posição A (spec, TP), na topicalização de PPs, o PP ocupa uma posição A'. Diferentemente do inglês, no espanhol, spec, TP é uma posição A'.

A pesquisadora mostra que as restrições sintáticas para que um PP ocupe uma posição pré-verbal evidenciadas para o inglês não são válidas para o espanhol. Nesta língua, os PPs invertidos aparecem com todos os tipos de V e podem ser tanto argumentos como adjuntos. Embora apresentem a restrição discursiva de que devem representar informação nova no discurso, os PPs fronteados não apresentam restrições sintáticas. Isso sustenta que spec, TP é uma posição A' no espanhol.

Seguindo a análise de Ordónez (1997), Kempchinsky (2001) mostra que nenhum SUJ DP precisa se mover para spec, TP para satisfazer o EPP pois o núcleo D/Agr por si só pode se mover para $\mathrm{T}$, fazendo com que o DP lexical permaneça in situ. Isso leva a autora a concluir que o movimento de um XP para a posição de SUJ no espanhol não é guiado por traços- $\Phi$ de $\mathrm{T}$, mas por traços-P associados à periferia esquerda. Assim, constituintes pré-verbais topicalizados ocupam a posição spec, TP nessa língua. Portanto, não há nenhuma construção de IL no espanhol a qual seja distinta da topicalização de PPs.

Mesmo assim, a autora analisa as propriedades semânticas e sintáticas de elementos topicalizados para estabelecer algumas diferenças entre SUJs pré-verbais e TOPs. Nesse sentido, Kempchinsky (2001) assume as definições de Casielles-Suárez (1999) e propõe que há dois tipos de TOP no espanhol - o TOP \#1 e o TOP \#2. Por meio de evidências de gramaticalidade em contextos “O que aconteceu?", comprova que os SUJs pré-verbais são TOPs do primeiro tipo, ao passo que elementos topicalizados constituem TOPs do segundo tipo. 


\section{Capítulo 2: Investigando o PB}

\subsection{Introdução}

Neste segundo capítulo, introduziremos alguns conceitos gerativistas e propostas teóricas da literatura do PB que serão essenciais para a análise da IL que apresentaremos no próximo capítulo. Para entendermos esse fenômeno lingüístico, teremos que, primeiramente, investigar onde se encaixa o PB dentro do parâmetro do sujeito nulo, como se dá a atribuição de Caso nominativo ao SUJ e em que contextos ocorre a inversão do SUJ nessa língua.

Nesse sentido, a primeira seção faz uma descrição do PB como uma língua prodrop parcial e, em seguida, mostra que a atribuição de Caso nominativo nessa língua parece estar disponível somente sob concordância. A seção seguinte apresenta uma revisão da literatura sobre o SUJ pós-verbal, partindo da Hipótese do Caso Partitivo e, posteriormente, passando pela Hipótese de Mono-Argumentalidade. Finalmente, a última seção apresenta sentenças com SUJs invertidos tanto com verbos mono-argumentais quanto com VTs, nas quais podemos observar que as sentenças com VTs e a ordem VS ocorrem em determinados contextos no $\mathrm{PB}$. O objetivo é mostrar que essa ordem não é uma ordem tão restrita, como consideram muitos estudiosos do assunto.

\subsection{O parâmetro pro-drop}

Um dos tópicos mais estudados pela Teoria Gerativa é a relação entre a riqueza flexional dos paradigmas verbais de uma língua e a possibilidade de omissão do sujeito em sentenças finitas. Essa relação deu origem à postulação do parâmetro conhecido como o parâmetro do sujeito nulo (PSN) ou parâmetro pro-drop (Chomsky, 1981), sob o qual as línguas podem ser agrupadas. Basicamente, as línguas que possuem um sistema "rico" de marcas de concordância número-pessoal nos verbos (Agr "rico") admitem SUJs vazios ou nulos pois sua interpretação pode ser recuperada a partir da desinência verbal.

A Teoria Gerativa também formulou o Princípio de Projeção Estendido (Extended Projection Principle (EPP)) o qual afirma que todo spec, IP deve estar preenchido em estrutura-S, ou seja, toda sentença deve ter um SUJ. As línguas românicas que apresentam a possibilidade de SUJ nulo estariam, em princípio, violando o EPP. Como conseqüência, 
foi postulado um SUJ nulo pronominal (pro), cuja identificação é feita por meio da concordância verbal.

Além da propriedade de apresentar SUJ nulo, as línguas que possuem o valor positivo para tal parâmetro também apresentam as seguintes características: inversão livre do SUJ em sentenças matrizes, movimento longo do SUJ a partir de uma ilha QU-, pronome resumptivo nulo em sentenças encaixadas e aparente violação do filtro that-trace. Os exemplos a seguir mostram os contrastes entre uma língua de SUJ nulo, o italiano, e uma língua não pro-drop, o inglês:

I. Possibilidade de apresentar SUJ nulo:

(63) a. Ha telefonato.

b. * Has phoned.

Tem telefonado.

II. Possibilidade de inversão livre do SUJ em sentenças matrizes:

(64) a. Ha telefonato Gianni. ${ }^{11}$

b. * Has phoned John.

Tem telefonado João.

III. Possibilidade de movimento longo a partir de uma ilha QU-:

(65) a. L'uomo [che mi domando [chi $t$ abbia visto]].

b. * The man [that I ask myself [whom $t$ has seen]].

\footnotetext{
${ }^{11}$ Os exemplos do italiano foram extraídos de Figueiredo Silva (1996: 30-31).
} 
O homem que me pergunto quem $t$ tenha visto.

IV. Possibilidade de pronome resumptivo nulo em sentenças encaixadas:

(66) a. Ecco la ragazza ${ }_{\mathrm{i}}$ [che mi domando [chi crede [che $t_{\mathrm{i}}$ possa fare questo]]].

b. * So the $\operatorname{girl}_{\mathrm{i}}$ [that I ask myself [that believe [that $t_{\mathrm{i}}$ can do this]]].

Eis a menina que eu me pergunto que acredita que (ela) possa fazer isto.

V. Possibilidade de violar aparentemente o filtro that-trace:

(67) a. Chi $_{\mathrm{i}}$ credi [che $t_{\mathrm{i}}$ partirà]?

b. ${ }^{*} \mathrm{Who}_{\mathrm{i}}$ do you think [that $t_{\mathrm{i}}$ will leave]?

Quem você pensa que partirá?

Partindo dessas propriedades, verificamos que as línguas que não apresentam SUJ nulo, como o inglês, não aceitam a inversão livre do SUJ, não realizam movimento longo do SUJ a partir de uma ilha QU-, não permitem a presença de um pronome resumptivo nulo em sentenças encaixadas e não apresentam violação do filtro that-trace.

Entretanto, o ponto crucial a distinguir entre as línguas seria a concordância (Agr), capaz de licenciar e permitir a recuperação do SUJ nulo em línguas de sistema flexional rico, como o italiano e o espanhol, línguas pro-drop prototípicas. Do outro lado, há as línguas que não permitem o SUJ nulo, como o inglês e o francês. O PB, que antes pertencia ao primeiro grupo, vem passando por um processo de mudança com relação a esse parâmetro.

A relação entre uma rica morfologia verbal e o licenciamento do SUJ nulo tem sido constantemente motivo de pesquisas e trabalhos sobre o SUJ nulo no PB desde que 
mudanças ocorreram no sistema morfológico da língua. Diferentemente do português europeu (PE), o SUJ nulo não é mais freqüente no PB. Para Duarte (1995), a redução do seu uso é resultado do enfraquecimento da morfologia verbal. Como o SUJ nulo deixou de ser comum na língua, a autora caracterizou o PB como língua de SUJ nulo "residual". Assim, o PB revelaria algumas diferenças com relação a uma típica língua pro-drop, permitindo uma aparente alternância entre SUJs nulos e SUJs pronominais plenos em determinados contextos.

Duarte (1995) levanta a hipótese de que o preenchimento gradual do SUJ nulo é uma mudança em progresso. Com o enfraquecimento da flexão morfológica dos verbos, houve um aumento considerável do preenchimento do SUJ, além de outras estratégias de preenchimento dessa posição sintática, como subordinadas com SUJ co-referente expresso e SUJs duplos (deslocados à esquerda). Segundo a autora, o PB estaria passando de uma língua pro-drop para não pro-drop:

Essa perda, entretanto, não se reflete no uso da língua como uma mudança concluída. O PB atual convive com um sistema agonizante, em que ainda se refletem as características pro-drop, e um sistema em desenvolvimento, em que a "riqueza funcional” perdida já não permite a identificação de pro.

É com base nessas observações que tenho me referido ao sujeito nulo em $P B$ como um pro residual. (...) Embora o sistema seja defectivo, os contextos que apresentam a categoria vazia são os mesmos em que o sujeito nulo é obrigatório naquelas línguas (pro-drop), não parecendo, pois, apropriado, propor um estatuto diferente para nossas ocorrências de sujeito nulo. Esta convivência de variantes incompatíveis é, na verdade, evidência de mudança em progresso. (Duarte 1995: 103)

$\mathrm{O}$ paradigma flexional do $\mathrm{PB}$, ao contrário do paradigma do italiano e do $\mathrm{PE}$, encontra-se simplificado. Esse paradigma, que no início do século XIX apresentava seis formas distintivas (cf. Duarte 1996), como em (68a), atualmente apresenta apenas três formas de concordância, como em (68b): 
(68) a. eu fal-o

tu fal-as

ele(a) fal-a

nós fal-amos

vós fal-ais

eles(as) fal-am b. eu fal-o

você fal-a

ele(a) fal-a

a gente fal-a

vocês fal-am

eles(as) fal-am

A substituição da $2^{\mathrm{a}}$ pessoa do singular $t u$ e do plural vós pela $2^{\mathrm{a}}$ pessoa indireta você e a substituição do pronome de $1^{\mathrm{a}}$ pessoa do plural nós pela expressão a gente enfraquecem o sistema flexional do PB. Com um paradigma flexional reduzido, o SUJ passa a ser cada vez mais pleno nessa língua pois, caso sua posição não seja preenchida, a concordância verbal não pode recuperá-lo na sentença.

Duarte (1996) verifica que, devido ao enfraquecimento do sistema flexional e pronominal no $\mathrm{PB}$, o SUJ nulo ocorre somente com a $3^{\mathrm{a}}$ pessoa na modalidade escrita (cf. 1996: 116, gráfico 4). Os SUJs de $1^{\mathrm{a}}$ e $2^{\mathrm{a}}$ pessoas são representados cada vez mais pelo pronome lexical ou um NP (cf. 1996: 113-115, gráficos (2)). A redução do paradigma flexional não mais possibilita a identificação do pronome nulo pro em posição de SUJ. Dessa forma, a possibilidade de SUJ nulo na $3^{a}$ pessoa não é livre, uma vez que depende da existência de um referente no contexto que possa identificar pro.

Na modalidade oral, há uma queda do SUJ nulo com a $3^{\mathrm{a}}$ pessoa e um aumento expressivo no uso do SUJ pleno. Na peça analisada pela autora, referente ao ano de 1992, os SUJs de $3^{\mathrm{a}}$ pessoa eram todos nulos no texto escrito. A análise da gravação da peça mostrou uma diminuição de $13 \%$ do SUJ nulo de $3^{\mathrm{a}}$ pessoa. Nos casos de $1^{\mathrm{a}}$ pessoa, a queda foi de $10 \%$ e, nos casos de $2^{\mathrm{a}}$ pessoa, nenhuma diferença significativa ocorreu.

Considerando os dados relativos à baixa freqüência do SUJ nulo apresentados por Duarte, verificamos que hoje a tendência é que o SUJ seja preenchido ao invés de ser nulo. Segundo a autora (1996: 123), a simplificação do paradigma flexional alterou as características de língua de SUJ nulo que o PB apresentava no início do século XIX. 
Atualmente é visto como uma língua pro-drop parcial, na qual o SUJ nulo apenas se mantém na língua escrita.

\subsection{A atribuição de Caso nominativo ao sujeito}

De acordo com o Filtro de Caso, toda cadeia de DP que se inicia dentro de IP deve receber Caso. Segundo tal princípio, o DP SUJ deve receber Caso nominativo da flexão INFL. Uma das maneiras de isso ocorrer é quando o $\mathrm{V}$ se move para I unindo-se à flexão e o SUJ se desloca para spec, IP para receber Caso nominativo de INFL. Nesse caso, o SUJ deixa um vestígio em sua posição de base e forma uma cadeia. Essa atribuição de Caso foi denominada atribuição sob concordância por Koopman \& Sportiche (1991) e está representada em (69):

(69) Atribuição sob concordância

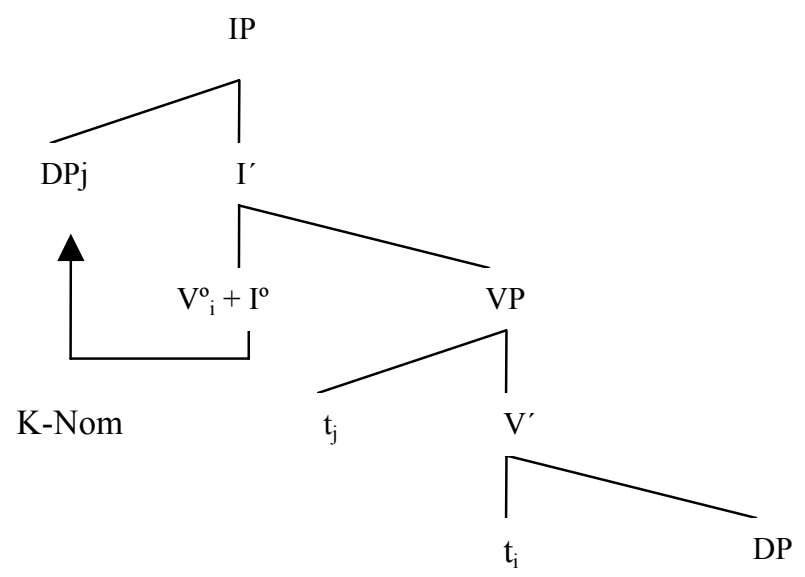

Como vemos nessa representação, a flexão está em uma relação de concordância especificador-núcleo com o SUJ $\left(\mathrm{DP}_{\mathrm{j}}\right)$. Tal atribuição de Caso ocorre em um contexto no qual o SUJ está em posição pré-verbal.

Os mesmos autores denominaram atribuição de Caso nominativo sob regência o tipo de configuração em que o SUJ está posposto ao V. Nessa forma de atribuição, a flexão 
está em uma posição mais alta na estrutura em relação ao $\mathrm{SUJ}\left(\mathrm{DP}_{\mathrm{j}}\right)$, como ilustrado abaixo:

(70) Atribuição sob regência

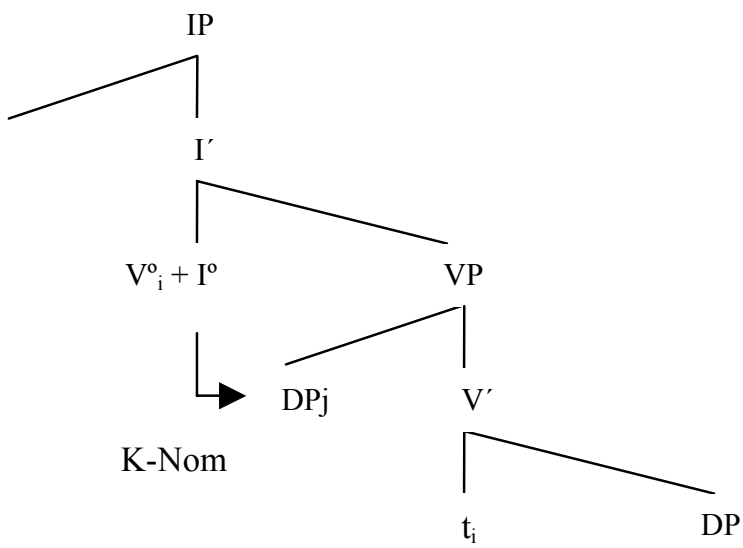

De acordo com essa representação, verificamos que o SUJ permanece in situ dentro do VP e o Caso é atribuído pela flexão ao especificador mais baixo $\left(\mathrm{DP}_{\mathrm{j}}\right)$, não por uma relação de concordância e sim, por regência.

Nas línguas, como o alemão, em que ocorre o movimento de I para C, o Caso nominativo pode ser atribuído sob regência ao constituinte que está em spec, IP (DP), como na configuração em (71):

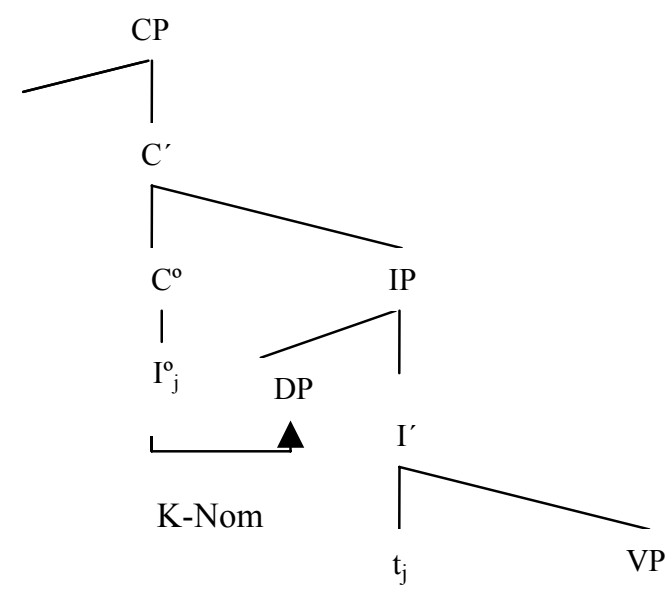


Figueiredo Silva (1996) estudando o SUJ pós-verbal no PB, compara esta língua com o italiano e propõe que a única forma de atribuir Caso nominativo no PB é sob a configuração de concordância. Entre as evidências dadas pela autora em favor da sua hipótese estão as interrogativas sim/não, exemplificadas em (72), e interrogativas QU-, exemplificadas em (73) (1996: 91):

(72) a. * Tinha telefonado o João?

b. * Tinha o João telefonado?

c. O João tinha telefonado?

(73) a. * O que (é) que tinha comprado o João nesse mercado?

b. * O que (é) que tinha o João comprado nesse mercado?

c. O que (é) que o João tinha comprado nesse mercado? ${ }^{12}$

Partindo desses exemplos, a autora verifica que o $\mathrm{PB}$ não possui construções do tipo Aux-to-Comp. As sentenças $(72 a, b)$ e $(73 a, b)$ ilustram esse tipo de construção, na qual o auxiliar se move para $\mathrm{C}$ e atribui Caso nominativo ao SUJ em spec, IP sob regência. Tais exemplos demonstram que quando isso ocorre a sentença é agramatical.

Figueiredo Silva oferece ainda outras três evidências que comprovam sua hipótese. Primeiramente, observa que o PB não permite a inversão sujeito-auxiliar nas construções condicionais, como mostra a agramaticalidade do exemplo em (75d). Ao contrário, no italiano, essa inversão é possível, como vemos no exemplo (74d) da autora (1996: 92):

(74) a. Se lui avesse capito al volo, tutto sarebbe andato bene.

b. * Lui avesse capito al volo, ...

c. ${ }^{*}$ Se avesse lui capito al volo, ...

d. Avesse lui capito al volo, ...

(75) a. Se ele tivesse compreendido rápido, tudo teria dado certo.

${ }^{12}$ Pilati (2002:14) discorda da generalização de que o PB não permite SUJ invertido em interrogativas QU-. A autora menciona os exemplos abaixo como ocorrências perfeitamente aceitáveis de SUJs pós-verbais em interrogativas QU- nessa língua:

(i) Onde (que) trabalha a Ana?

(ii) O que (que) pensa uma pessoa dessa? 

b. * Ele tivesse compreendido rápido, ...
c. * Se tivesse ele compreendido rápido, ...
d. * Tivesse ele compreendido rápido, ...

No italiano, o $\mathrm{V}$ auxiliar sobe para $\mathrm{C}$, ocupando o lugar do complementizador se, de onde é capaz de reger o SUJ em spec, IP e lhe atribuir Caso nominativo, exatamente o que acontece em (74d). A impossibilidade de (75d) deve-se ao fato de o V não ter subido para C, portanto, não consegue reger o SUJ. Por sua vez, a sentança em (75c) é agramatical pois o complementizador se e o $\mathrm{V}$ auxiliar não podem estar simultaneamente em $\mathrm{C}$, já que disputam a mesma posição.

Outro argumento apontado pela autora diz respeito às construções no subjuntivo. $\mathrm{O}$ italiano permite que o complementizador que seja opcionalmente apagado, como em (76a). Tal apagamento torna-se obrigatório se o auxiliar precede o SUJ, como podemos ver em (76b) (1996: 92):

(76) a. Speravo (che) tu fossi disposto ad aiutarci.

b. Speravo (*che) fossi tu disposto ad aiutarci.

Mesmo em construções com complementos no subjuntivo, o complementizador que no PB nunca pode ser apagado, como vemos em (77a) a seguir, por isso, ainda que o auxiliar preceda o SUJ da oração subordinada, como em (77b), o complementizador deve ocorrer na sentença.

(77) a. Eu esperava *(que) você estivesse disposto a ajudar a gente.

b. * Eu esperava (que) estivesse você disposto a ajudar a gente.

Assim, (77b) é agramatical porque o complementizador que impede que o auxiliar suba para $\mathrm{C}$ e atribua caso Nominativo ao SUJ.

Por fim, Figueiredo Silva compara o PB com o inglês em relação às construções com um elemento negativo inicial. No inglês, esse tipo de construção ocasiona a inversão sujeito-auxiliar (78a), mas no $\mathrm{PB}$, mesmo com a presença de um elemento negativo iniciando a sentença encaixada, a sentença é agramatical (78b). A única opção possível é (78c) (1996: 93): 
(78) a. John said that under no circumstances would he do that.

b. * O João disse que de jeito nenhum ia ele fazer uma coisa dessas.

c. O João disse que de jeito nenhum (que) (ele) ia fazer uma coisa dessas.

Comparando o PB com fatos do italiano e do inglês, a pesquisadora conclui que o PB não tem a opção paramétrica de atribuição de Caso nominativo sob regência, o que explica a ausência de SUJs pós-verbais na língua. Figueiredo Silva admite que o SUJ esteja invertido somente nos contextos em que o V é inacusativo e seu argumento DP é indefinido. Neste caso, o SUJ recebe o Caso partitivo proposto por Belletti (1988), que veremos na próxima seção.

\subsection{A inversão do sujeito}

\subsubsection{A hipótese do Caso partitivo}

Como acabamos de ver, Figueiredo Silva (1996) considera que o PB não aceita SUJs pós-verbais pelo fato de a língua não poder atribuir Caso nominativo sob regência. Para explicar o Caso recebido pelos SUJs invertidos que sejam argumentos internos de verbos inacusativos, a autora faz uso da proposta de Belletti (1988), a qual sugere que tais DPs recebem Caso partitivo.

Segundo Figueiredo Silva, essa autora discorda da proposta de Burzio (1986) de atribuição de Caso nominativo ao SUJ pós-verbal por cadeia, por meio da co-indexação do SUJ posposto com um pro expletivo em spec, IP. Belletti argumenta que, na atribuição de Caso ao SUJ de um V inacusativo, o VP constitui uma barreira que impede que a flexão de reger o DP pós-verbal, não havendo, assim, transmissão de Caso a esse constituinte. Dessa forma, Belletti propõe que o argumento interno do $\mathrm{V}$ inacusativo, embora não possa receber Caso acusativo, pode ser marcado pelo Caso partitivo. Este caso é um Caso inerente pois é atribuído junto com a função temática do constituinte em estrutura-D.

Para Belletti, a Hipótese do Caso Partitivo pode solucionar problemas relacionados ao Efeito de Definitude (Definiteness Efect (DE)). Esse Caso só pode ser atribuído aos constituintes indefinidos que podem ser interpretados como parte de um conjunto. Desse modo, estão excluídos da posição marcada por este Caso os quantificadores universais e os 
constituintes definidos. A autora ressalta que, quando um DP [+ definido] é interpretado como membro de um conjunto, ocorrendo em uma leitura de lista, este também pode receber o Caso partitivo.

As sentenças existenciais do inglês formadas pelo expletivo there, cujos verbos não são capazes de atribuir Caso acusativo a seus argumentos internos, não aceitam que o SUJ seja um DP definido, como mostra (79b), ou um DP modificado por um quantificador universal, como em $(79 \mathrm{c})$ :

(79) a. There is a man in the garden.

Tem um homem no jardim.

b. * There is the man in the garden.

Tem o homem no jardim.

c. ${ }^{*}$ There is every man in the garden.

Tem todo homem no jardim.

O argumento interno das sentenças acima não pode receber Caso acusativo. Nesses exemplos, tal argumento é marcado pelo Caso partitivo. O contraste entre (79a) e (79b, c) confirma a hipótese de Belletti de que o sintagma que recebe Caso partitivo sofre DE. Por isso, nas sentenças existenciais do inglês e naquelas formadas por verbos incapazes de atribuir Caso acusativo a seus argumentos internos, estes devem ter uma leitura indefinida.

Figueiredo Silva (1996: 98), citando Belletti, apresenta a estrutura em (80) para mostrar as possíveis posições de um NP/DP na sentença:

(80) $\mathrm{NP}_{1}\left[\begin{array}{llllll}\mathrm{vP} & {[\mathrm{vp}} & \mathrm{V} & \mathrm{NP}_{2} & {\left[\begin{array}{lll}\mathrm{PP} & \mathrm{P} & \mathrm{NP}_{3}\end{array}\right]} & \mathrm{NP}_{4}\end{array}\right]$

No caso da atribuição de Caso partitivo, a única posição disponível para o argumento interno é $\mathrm{NP}_{2}$. Nas línguas de SUJ nulo, como o italiano, quando a sentença apresenta um V inacusativo e um SUJ definido, o constituinte pós-verbal não é marcado pelo Caso partitivo, pois recebe Caso nominativo sob regência. 
Para explicar os casos de inversão no PB, Figueiredo Silva adota a proposta de Belletti (1988) por julgar agramaticais todas as sentenças com verbos inacusativos nas quais o SUJ pós-verbal é um DP definido. Consideremos as seguintes sentenças (1996: 9495):

(81) a. Tem um homem no jardim.

b. * Tem o homem no jardim.

(82) a. Desapareceu um livro.

b. * Desapareceu o livro.

(83) a. Foi morto um homem.

b. * Foi morto o homem.

De acordo com Figueiredo Silva, as sentenças com verbos existenciais (81a, b), verbos inacusativos $(82 \mathrm{a}, \mathrm{b})$ e verbos na voz passiva $(83 \mathrm{a}, \mathrm{b})$ somente permitem o licenciamento do SUJ posposto sob a forma indefinida. A única posição disponível para os argumentos internos dessas sentenças é a posição interna ao VP, onde o DP pós-verbal é marcado pelo Caso partitivo.

Embora adotando a hipótese do Caso partitivo, o qual é atribuído apenas aos argumentos internos de verbos inacusativos e existenciais, Figueiredo Silva aceita algumas sentenças com VIs e SUJ, como em (84) (1996: 97):

(84) a. Telefonou um cara aí pra você.

b. Viajou uma mulher supergorda do meu lado.

A explicação dada pela autora com relação à aceitabilidade dessas sentenças é que alguns VIs do PB estão passando por um processo de "ergativização". Nos exemplos citados, os argumentos recebem Caso partitivo e são licenciados sob a forma de DPs indefinidos.

Para mostrar que somente certos tipos de VIs sofrem esse processo, a autora mostra algumas sentenças agramaticais com VIs e DPs indefinidos pós-verbais (1996: 97): 
(85) a. * Tossiu/Estava tossindo um cara atrás de mim.

b. * Espirrou/Estava espirrando um cara durante o filme.

Figueiredo Silva conclui que o PB permite que o SUJ ocupe uma posição pós-verbal à condição de que seja interpretado como objeto profundo, isto é, apenas nos casos de verbos inacusativos e alguns intransitivos sofrendo "ergativização". Nesses contextos, os DPs recebem Caso partitivo e devem ocupar posições de argumentos internos.

Seguindo o trabalho de Pilati (2002), propomos que a hipótese do Caso partitivo não seja a opção teórica mais adequada para o PB. Nessa língua, é possível que o SUJ esteja em uma posição pós-verbal com verbos inacusativos e intransitivos sem ser licenciado sob a forma indefinida. Quando o V seleciona apenas um argumento, como em (86a), ou a sentença contém um operador foco, como no caso do operador só em (86b), as orações são perfeitamente gramaticais, mesmo que o SUJ pós-verbal seja definido.

(86) a. Ali moram os meninos. (Pilati 2002: 31)

b. Só não responderam a chamada os alunos do fundão. (Pilati 2002: 36)

A autora contraria a proposta de Figueiredo Silva de que alguns VIs estão sofrendo uma "reanálise ergativa" na língua, enquanto outros não. Pilati (2002: 27-28) constrói um contexto no qual as sentenças em (85) são aceitáveis, como no caso de o falante narrar um acontecimento que tenha vivido ou presenciado com a finalidade de enfatizar a ação praticada por uma personagem da narrativa. A situação é a seguinte: um grupo de amigos está comentando, na saída do cinema, que havia muitas pessoas resfriadas na sala em que estavam assistindo ao filme.

(87) A: Nossa! Tinha muita gente resfriada no cinema. 'Tava todo mundo espirrando. ${ }^{13}$

B: Graças a Deus, atrás de mim, só espirrou a sua prima.

C: Eu mudei de lugar depois que tossiu um cara atrás de mim. Não quero pegar gripe de ninguém.

\footnotetext{
${ }^{13}$ Os grifos são da autora.
} 
Como o objetivo é ressaltar a ação da personagem, o falante inicia a sentença com o $\mathrm{V}$ deixando o sujeito posposto. Os DPs pós-verbais em (87A, B) aparecem, respectivamente, junto do quantificador todo e sob a forma definida, contextos nos quais não há espaço para o Caso partitivo.

\subsubsection{A hipótese de mono-argumentalidade}

As línguas românicas classificadas como pro-drop apresentam, conforme as propriedades do PSN, a possibilidade de manter o SUJ em posição pós-verbal, originando as construções conhecidas por inversão livre, como no caso do italiano, do PE e do espanhol, respectivamente:

(88) a. Ha telefonato Gianni.

b. Telefonou o João.

c. Ha llamado Juan.

O PB, apesar de seu status de língua românica, parece se afastar dessas línguas no que diz respeito às construções de inversão livre. Seguindo o conjunto de propriedades proposto por Chomsky (1981) como característico das línguas de SUJ nulo, verificamos que o PB não se comporta como uma língua pro-drop prototípica, sendo considerado por alguns autores uma língua pro-drop parcial. Tal parcialidade resulta da alta freqüência de SUJs preenchidos e do baixo número de SUJs nulos na modalidade falada.

Pilati (2002), citando o trabalho de Kato \& Tarallo (K\&T 1993), constata que a inversão livre não funciona em uma língua como o PB ou, pelo menos, que a inversão deve obedecer a algumas restrições, como vemos na agramaticalidade dos exemplos abaixo ${ }^{14}$ :

(89) a. * Tomaram muitas cervejas os professores.

b. * Enviou-lhe muitos beijos o Romeu.

A autora apresenta a Hipótese de Mono-Argumentalidade de K\&T (1993) através da qual afirmam que o SUJ esteja posposto ao $\mathrm{V}$ apenas com verbos de um único argumento, como

\footnotetext{
${ }^{14}$ Todos os exemplos de Kato \& Tarallo (1993) foram retirados de Pilati (2002).
} 
os inacusativos e os intransitivos, como ilustram os exemplos (90a) e (90b), respectivamente:

(90) a. Chegou um telegrama pra você.

b. Viajou atrás de mim uma criança.

Já Berlinck (1989) aponta que o SUJ invertido não deve ocorrer com verbos de mais de um argumento no PB por uma questão de ambigüidade. As construções transitivas com SUJ pós-verbal podem atribuir uma interpretação equívoca ao SUJ, uma vez que este pode vir a ser interpretado como OBJ.

O sistema de clíticos possibilita que as construções transitivas sejam fonologicamente mono-argumentais, podendo, assim, apresentar a inversão do SUJ. De acordo com Berlinck, o clítico guardaria o seu caráter referencial, permitindo a recuperação do sentido transitivo do $\mathrm{V}$ e das relações que este mantém com os seus argumentos. Dessa forma, impediria a ambigüidade das construções. Um sistema de clíticos enfraquecido, como se apresenta o do PB, impede esse jogo de compensações e, conseqüentemente, colabora com a diminuição do uso do SUJ pós-verbal com VTs.

Segundo Pilati, K\&T concordam com Berlinck, dizendo que a perda dos clíticos reflete na ausência de SUJs pós-verbais. Os autores afirmam que a inversão do espanhol não deveria ser considerada livre, pois funciona com VTs apenas quando o OBJ está cliticizado, como se vê em (91a). Em contextos com verbos de três argumentos, todos os OBJs devem ser clíticos, como em (91b):

(91) a. Lo instaló Esteban.

Instalou-o Esteban.

b. Se lo iba a decir el estudiante.

(Lhe) ia dizê-lo o estudante.

Se o clítico funciona como um redutor de argumentos, o espanhol também possui a restrição mono-argumental. O mesmo pode ser dito para o italiano, uma vez que as construções com inversão do SUJ são mais aceitáveis se o OBJ for um clítico, como demonstram os exemplos dados pelos autores: 
(92) a. L'ha mangiata la mamma.

b.? Ha mangiato la torta la mamma.

Comeu o bolo a mãe.

A hipótese de K\&T é a de que a restrição mono-argumental funciona como uma restrição sensitiva ao material fonológico pronunciado e não ao número de argumentos selecionados pelo V. Por isso, a má formação da ordem VS com VTs estaria relacionada à PF (Phonological Form). Para alguns estudiosos, a falta de um sistema rico de clíticos, torna o PB uma língua menos produtiva em processos de inversão. Isso acontece porque o uso freqüente de um pronome lexical não favorece a posposição do SUJ. Ainda assim, Pilati mostra alguns casos residuais de clíticos co-ocorrendo com a inversão. Citando K\&T, a autora aponta que a ordem VS pode ocorrer no PB quando o OBJ é o clítico me e te, como vemos abaixo:

(93) a. Me surpreendeu a notícia.

b. A notícia me surpreendeu.

(94) a. Te surpreendeu a notícia?

b. A notícia te surpreendeu?

(95) a. A notícia surpreendeu você?

* Você surpreendeu a notícia?

b. A notícia surpreendeu ele.

* Ele surpreendeu a notícia.

c. A notícia surpreendeu a gente.

* A gente surpreendeu a notícia.

Em (93a) e (94a), os OBJs cliticizados me e te permitem que o SUJ a notícia apareça posposto ao V surpreendeu. Já nas sentenças em (95), a inversão não ocorre porque não há mais ocorrências de clítico acusativo de $3^{\mathrm{a}}$ pessoa, assim, os pronomes você, ele e a gente não podem ser cliticizados. 


\subsubsection{Outras construções com sujeitos pós-verbais}

Em estudo sobre a ordem verbo-sujeito no PB, Pilati (2002) faz uma descrição do trabalho de Kato \& Tarallo (1993) no qual propõem que há dois tipos de estruturas que descrevem a ocorrência da sintaxe VS do PB: V-fronting (Fronteamento do V) e Right Dislocation (Deslocamento à Direita ou Falsa Inversão). E, que essas duas estruturas são sensíveis à restrição de mono-argumentalidade.

$\mathrm{O}$ fronteamento do $\mathrm{V}$ ocorre quando o $\mathrm{V}$ é mono-argumental e se move para I e o SUJ permanece na sua posição de base, ou seja, em spec, VP. Normalmente, o movimento do $\mathrm{V}$ é desencadeado por algum constituinte que aparece no início da sentença, como as expressões interrogativas (96a) e advérbios dêiticos (96b) (K\&T 1993 apud Pilati 2002: 31):

(96) a. Onde moravam os meninos?

b. Ali moravam os meninos.

Na derivação dessas sentenças, as palavras que aparecem em posição inicial se movem para uma posição fora do IP, na periferia esquerda da sentença. $\mathrm{O} V$ une-se à flexão e o sujeito permanece em $s p e c, V P$, como ilustra a seguinte derivação:

(97) $\left[\mathrm{CP} \mathrm{Ali}_{\mathrm{k}}\left[\mathrm{IP}\left[\mathrm{I}, \operatorname{moravam}_{\mathrm{i}}\left[\mathrm{vP}\right.\right.\right.\right.$ os meninos $\left.\left.\left.\left.\left[\mathrm{v}, \mathrm{t}_{\mathrm{i}} \mathrm{t}_{\mathrm{k}}\right]\right]\right]\right]\right]$

Nas sentenças em (96), o V seleciona mais de um argumento. Segundo Pilati, o conceito de "argumento" para K\&T diz respeito à qualquer tipo de elemento selecionado, seja nominal ou adverbial. De acordo com os autores, essas sentenças são possíveis porque os vestígios do argumento não contam para a restrição de mono-argumentalidade. Assim, essa restrição tem uma natureza fonética ou rítmica e os vestígios não são visíveis para a interface fonética.

Por sua vez, a falsa inversão caracteriza-se por apresentar o SUJ deslocado à direita e um pronome expletivo (pro), como em (98b), ou um pronome referencial, como ilustra (98c), na posição de SUJ. O emprego do pro ou do pronome referencial em posição inicial 
possibilita a falsa inversão. Tal denominação decorre do fato de que essas construções, mesmo apresentando o SUJ posposto, não devem ser confundidas com as construções de inversão livre das línguas pro-drop. Os exemplos são de K\&T (1993 apud Pilati 2002:31).

(98) a. O vestido azul tá pronto.

b. pro Tá pronto o vestido azul.

c. Ele tá pronto, o vestido azul.

Os autores propõem que nas sentenças $(98 \mathrm{~b}, \mathrm{c})$ o SUJ pós-verbal está deslocado à direita em uma posição não-argumental, semelhante àquela ocupada por um elemento em adjunção. Essa construção possibilita a presença de um pronome na posição do SUJ, que pode ser um pro expletivo ou referencial. A estrutura proposta para o SUJ posposto é a seguinte:

(99) $\left[\left[\right.\right.$ IP pro/ele $_{\mathrm{k}}$ [I, (es)tá $\left[\mathrm{vP}_{\mathrm{k}}\left[\mathrm{v}, \mathrm{t}_{\mathrm{i}}\right.\right.$ pronto $\left.\left.\left.]\right]\right]\right]$ o vestido azul $\left.\mathrm{k}_{\mathrm{k}}\right]$

Seguindo essa representação, verificamos que o antitópico está em adjunção ao IP. K\&T afirmam que tal constituinte não precisa de Caso porque é um predicativo do sujeito pro/ele. Além disso, os autores observam que as construções com SUJ deslocado à direita não sofrem DE, uma vez que normalmente os DPs deslocados são definidos.

A maioria dos pesquisadores que estudam o comportamento do SUJ no PB adota a hipótese de mono-argumentalidade e aceita que o SUJ apareça em uma posição pós-verbal somente nos contextos em que o V é inacusativo ou intransitivo. Entretanto, Pilati (2002) fornece exemplos em que o $\mathrm{V}$ apresenta um argumento interno realizado e um sujeito pósverbal, revelando a ordem VOS.

De acordo com a autora, a seqüência VOS deve ser dividida em três grupos: o primeiro contém sentenças com VT e um SUJ que não é modificado por um operador foco, como em (100); o segundo apresenta sentenças com VT e um SUJ modificado por um operador foco só, como em (101); e o terceiro engloba sentenças contendo verbos-leve ${ }^{15}$, como em (102) (2002: 35-36):

\footnotetext{
${ }^{15}$ Pilati (2002) adota a função discursiva do $\mathrm{V}$ informacionalmente leve tal como foi proposta para a IL no inglês por L\&RH (1995) (cf. seção 1.2).
} 
(100) a. Tem a palavra a Senadora Heloísa Helena.

b. Merece destaque a nova seção deste jornal.

c. Pega fogo a disputa eleitoral no São Paulo Futebol Clube.

d. Vence a partida quem permanecer em jogo depois que os demais forem desclassificados.

(101) Só responderam a chamada os alunos do fundão.

(102) a. Tomou posse o Ministro da Agricultura.

b. Também faz parte do programa a professora Renata Silva.

Os dados de Pilati são exemplos de sentenças apresentativas as quais revelam que a restrição de mono-argumentalidade não deve ser vista como o único fator capaz de permitir a inversão do SUJ no PB. Ainda assim, ressaltamos que realmente ocorre com mais freqüência na língua a inversão do SUJ com verbos mono-argumentais.

Para Figueiredo Silva (1996), nos casos em que a inversão sujeito-verbo com VIs (103a) e com VTs (103b) ocorre no PB, estamos diante de construções de falsa inversão, conforme aquelas propostas por K\&T (1993). O SUJ é interpretado como TOP estando à direita do VP e há possibilidade de um pronome estar em spec, IP retomando o SUJ posposto. Assim, mesmo em construções transitivas o SUJ posposto não causa nenhum efeito de interferência com o objeto, como ocorre no italiano.

(103) a. (Eles) correram, os meninos.

b. (Elas) comeram o bolo, as crianças.

Partindo dessa proposta, a autora afirma que a posição ocupada pelo SUJ pósverbal nas construções não-inacusativas no PB não deve ser a mesma daquela ocupada pelo SUJ invertido nas mesmas construções no italiano. Independentemente de qual for a posição à direita, admitida para os SUJs pós-verbais do italiano (spec, VP ou spec, FocP), esta não ocorre no PB por questões que dizem respeito à atribuição de Caso. Em nota, Figueiredo Silva (1996: 104, nota 14) aponta que a diferença entre o PB e o italiano pode 
estar relacionada à falta da categoria FocP à direita no $\mathrm{PB}$, estando esta categoria presente no italiano. No entanto, veremos no próximo capítulo que a periferia esquerda de VP tem um efeito sintático no PB.

Pilati questiona o fato de o SUJ pós-verbal estar topicalizado e em adjunção nas construções em que aparece à direita do V, como no exemplo (103b), pois, em muitos contextos, o SUJ não é interpretado como TOP e está dentro da sentença, não em adjunção. A autora (2002: 38-39) cria uma situação discursiva na qual uma moça pergunta à sua costureira se as roupas que ela encomendou estão prontas, como em (104A), e a costureira responde com (104B):

(104) A: Quais as minhas roupas que estão prontas?

B: Só tá pronto o vestido azul. (as outras peças não estão prontas)

Em (104B), o operador foco só tem escopo sobre o SUJ pós-verbal, por isso, não há como afirmar que o SUJ esteja deslocado à direita nem que tenha a interpretação de TOP. Até mesmo porque, nesse contexto, o SUJ é a informação não-pressuposta, o FOC. Dessa forma, a única posição disponível para o SUJ posposto é spec, FocP acima de VP, como mostraremos no próximo capítulo.

O contrário ocorre se mudamos o contexto discursivo, como no caso de a moça perguntar à costureira se já pode levar seu vestido para casa (105A) e a costureira responde (105B):

(105) A: Já posso levar pra casa?

B: Não. Ele $\mathrm{i}_{\mathrm{i}}$ só tá pronto, o vestido $\mathrm{azul}_{\mathrm{i}}$. (mas ainda não está passado, nem engomado)

Em (105B), o operador foco só não tem mais escopo sobre o SUJ posposto, mas sobre o predicativo pronto. Nesse caso específico, o SUJ não é mais a informação não-pressuposta, podendo ser interpretado como TOP.

Nos contextos de sentenças apresentativas, a inversão ocorre sem restrições quanto ao tipo de V e definitude do DP posposto. Isto pode ser visto em (106), onde temos um locativo iniciando a sentença, e em narrativas de jogo de futebol, como ilustra (107) (2002: 72): 
(106) a. Para São Paulo, viajou o João.

b. Naquela praça, estão as crianças.

c. No shopping da Trindade, comem os universitários.

(107) a. Abre o placar o time do Palmeiras.

b. Ergue o braço o juiz.

A discussão a respeito do SUJ pós-verbal no $\mathrm{PB}$, bem como os dados avaliados, revela que, contrário ao que a maioria das propostas teóricas gerativistas defendem, a ocorrência de SUJs pospostos não está restrita aos verbos mono-argumentais. Além disso, parece que o tipo de $\mathrm{V}$ está deixando de ser o fator principal nos casos de inversão. Dependendo da função semântica e sintática e do acento fonológico do SUJ em uma determinada sentença, o SUJ pode ser licenciado em posição pós-verbal, independentemente de ser definido ou não, e de o $\mathrm{V}$ apresentar um ou mais argumentos realizados fonologicamente.

\subsection{Resumo do capítulo}

Com relação ao parâmetro do sujeito nulo, vimos que atualmente o PB pode ser considerado uma língua pro-drop parcial, pois ainda mantém o SUJ nulo de $3^{\text {a }}$ pessoa na sua modalidade escrita, apesar do aumento expressivo do seu uso pleno principalmente na modalidade oral. Devido à sua condição de língua pro-drop parcial, é de se esperar que a inversão do SUJ também seja parcial, determinada por alguns fatores.

O primeiro fator que estaria restringindo a existência de uma inversão livre no PB seria a perda da atribuição de Caso nominativo sob regência, apontado por Figueiredo Silva (1996). Pela sua análise, SUJs pós-verbais só podem ser licenciados em sentenças com verbos inacusativos. Assumindo a hipótese do Caso partitivo de Belletti (1988), a mesma autora sustenta que os DPs argumentos de verbos inacusativos recebem o Caso partitivo e, conseqüentemente, ficam submetidos ao efeito de definitude.

Para outros pesquisadores, como Kato e Tarallo (1993), outros fatores condicionantes para a existência de SUJs pospostos no PB seriam a presença obrigatória de 
verbos mono-argumentais nas inversões e a perda dos clíticos. No entanto, vimos, através de Pilati (2002) algumas construções em que a inversão ocorre sem que o verbo seja inacusativo e o DP argumento indefinido. E, ainda, que dependendo do contexto discursivo o SUJ pós-verbal não é TOP e nem está em adjunção com um pronome co-referente a ele em spec, IP.

Assim, assumimos que esses fatores apresentados não conseguem dar conta de explicar as ocorrências de SUJs pós-verbais no PB e que, ao contrário do que muitos pesquisadores dizem, a ordem VS não é uma ordem tão restrita assim. Parece que há outros fatores mais fortes que desencadeiam a inversão nessa língua, como a presença de um LOC ou um operador foco em posição inicial e a existência de uma função apresentativa dessas construções, que pressupõe que o SUJ invertido seja interpretado como o FOC da sentença. 


\section{Capítulo 3: A Inversão Locativa no Português Brasileiro}

\subsection{Introdução}

A construção da IL constitui-se atualmente como um fenômeno lingüístico exaustivamente estudado e descrito em línguas como o inglês e o espanhol, conforme vimos no primeiro capítulo. Entretanto, quando pesquisamos sobre o fenômeno na literatura do português, não encontramos muitas descrições ou análises a seu respeito. A IL ainda permanece como um fenômeno pouco descrito nessa língua.

Com o objetivo de propor uma descrição para a construção no PB, apresentaremos, na primeira seção deste capítulo, algumas descrições do fenômeno disponíveis na literatura do português. Partimos de um dos primeiros trabalhos sobre a IL, em que Barbosa (1989) nos oferece algumas intuições iniciais para uma análise do fenômeno. Em um trabalho mais recente, mostramos que Pilati (2002) descreve as construções de IL como um dos tipos de sentenças apresentativas. Relacionando a função discursiva das sentenças apresentativas à IL, mostramos que Quarezemin (2006) propõe que estas construções são motivadas por tal função discursiva pelo fato de seus SUJs serem interpretados como o FOC das sentenças.

Por fim, apresentamos uma proposta de análise para a IL, mostrando que a construção apresenta algumas semelhanças em relação às construções de topicalização sem preposição. Além de propor uma análise para a IL no PB, nosso objetivo é mostrar a importância de tal fenômeno num âmbito maior dos estudos da gramática do PB, considerando que a IL pode ser um indício que caracterizaria o PB como uma língua de traço EPP.

\subsection{A inversão locativa na literatura do português}

\subsubsection{Um primeiro diagnóstico}

Nesta seção, apresentamos um trabalho sobre os LOCs na posição de SUJ no PE. Nesse estudo, Barbosa (1989) não chega a fazer uma análise da IL propriamente dita, mas faz um primeiro diagnóstico da relação entre a localização espaço-temporal, a inacusatividade e a presença de LOCs em posição inicial nas sentenças. Seu trabalho, apesar de incipiente e de apresentar alguns julgamentos teóricos que consideramos 
equivocados, pode ser considerado um dos estudos pioneiros sobre o fenômeno da IL no português e nos ajuda a pensar alguns aspectos importantes para a análise que apresentaremos mais adiante.

A autora inicia seu artigo estabelecendo uma comparação entre dois verbos copulativos no português - ser e estar. Seguindo as definições de Kratzer (1988), Barbosa os define da seguinte forma ${ }^{16}$ :

SER is selected by individual-level adjectival predicates and ESTAR is selected by stage-level adjectival predicates.

Assim, esses dois verbos copulativos exibem comportamentos sintáticos distintos, como podemos observar nos exemplos dados pela autora:

(108) a. Alguns estudantes estavam doentes.

b. Estavam estudantes doentes.

(109) a. Alguns estudantes eram inteligentes.

b. Eram estudantes inteligentes.

(110) a. Os estudantes estavam.

b. Estavam estudantes.

(111) a. * Os estudantes eram.

b. Eram estudantes.

De acordo com Barbosa (1989), o paradigma acima mostra que, nas sentenças com o V ser, spec, IP é uma posição temática, isto é, uma posição à qual é atribuído um papel $\theta$ pelo predicador adjetival. Esta é a razão da agramaticalidade em (111a): o SUJ não recebe papel $\theta$. A sentença em (109b) só pode ser considerada bem formada se se assume que há um pro em spec, IP.

\footnotetext{
${ }^{16}$ Nossa versão do artigo de Barbosa (1989) não apresenta a numeração das páginas.
} 
As sentenças com o $\mathrm{V}$ estar apresentam um comportamento diferente. Como demonstrado em (108b) e (110b), nenhum papel $\theta$ é atribuído a spec, IP pois, segundo Barbosa, tal posição não precisa ser preenchida por um argumento ${ }^{17}$. Dessa forma, o NP [estudantes] em (108b) recebe papel $\theta$ e Caso partitivo do V, o que é confirmado pelo efeito de definitude sofrido pelo NP. A autora conclui que, enquanto ser se comporta como uma cópula genuína na qual o V liga um SUJ a um predicativo, estar parece ter todas as características de um $\mathrm{V}$ inacusativo.

A partir disso, a autora levanta a seguinte pergunta: Por que a cópula de nível de estado deveria se comportar sintaticamente como um V inacusativo? Retomando Kratzer (1988), Barbosa sugere que predicados de nível de estado contêm um argumento extra para localizações espaço-temporais e que expressões locativas deveriam ser analisadas como predicados desse argumento. $\mathrm{Na}$ ausência de uma expressão locativa, o valor desse argumento é suprido pelo contexto do uso.

Barbosa mostra que, no PE, um LOC pode preceder o V, mas quando ambos, SUJ e LOC, precedem o V, o LOC não pode preceder o SUJ, conforme mostram seus exemplos:

(112) a. Ali está a Maria.

b. A Maria está ali.

c. * Ali a Maria está.

(113) a. Ali apareceu um gato.

b. O gato apareceu ali.

c. * Ali o gato apareceu.

As sentenças em (113) sugerem que verbos inacusativos vão apresentar o mesmo comportamento observado para o V estar em (112). Isso leva a autora a questionar que tipo de relação a localização espaço-temporal estabeleceria com a inacusatividade. Na tentativa de encontrar alguma resposta para a sua pergunta, Barbosa recorre a um trabalho de Vincenzi (1989) sobre o processamento de SUJs nulos no italiano com verbos inacusativos e inergativos.

\footnotetext{
${ }^{17}$ Não concordamos com essa afirmação tampouco com a gramaticalidade das sentenças em (108b) e (110b).
} 
Vincenzi (apud Barbosa 1989) define os verbos inacusativos como aqueles que se referem a situações dinâmicas no mundo extra-lingüístico as quais estão sem o controle de um agente, isto é, acontecimentos sem uma mudança de estado. Já os verbos inergativos são aqueles que denotam situações sob o controle de um agente, atos, ações ou processos nos quais um agente produz uma mudança de estado. Nesse sentido, a autora italiana afirma que uma localização espaço-temporal é essencial na descrição lingüística de uma mudança de estado.

Da mesma forma que Barbosa, a autora segue Kratzer (1988) assumindo que todos predicados de nível de estado selecionam um argumento extra de localização espaçotemporal. No caso de sentenças com verbos inacusativos, já que o NP pode ser realizado na posição de OBJ quando for indefinido, o argumento LOC pode ser realizado em spec, IP. Quando isso acontece, a realização fonética tem a função pragmática de predicar uma mudança no estado de uma localização espaço-temporal.

Segundo Barbosa, Vincenzi sustenta sua análise mostrando que, no italiano, PPs podem ser SUJ e que, nas sentenças em que LOCs PPs precedem um V inacusativo, os LOCs podem atuar como antecedentes para pro ou como controladores para PRO. Tal fato serve como uma evidência de que o PP tem a opção de ser um argumento na representação sintática de um $\mathrm{V}$ inacusativo, o que não acontece com um $\mathrm{V}$ inergativo.

Barbosa aponta que o fato crucial para a análise de Vincenzi é que o NP deve ser indefinido. Somente nesse caso, a posição spec, IP está disponível para o argumento LOC. No entanto, a primeira autora observa que muitas sentenças envolvendo um FOC apresentacional no PE não requerem que o NP seja indefinido. Requerem que o NP adicione informação nova, mas não precisa necessariamente ser indefinido, como ilustram os exemplos fornecidos pela autora:

(114) a. Junto da praia apareceu o corpo do estudante desaparecido.

b. Junto da praia apareceu um corpo não identificado.

Como vemos em (114a), o NP/DP argumento do V inacusativo é perfeitamente aceitável mesmo sendo definido, pois representa a informação nova no discurso, contituindo, assim, um FOC apresentacional. De acordo com Barbosa, alguns verbos inacusativos contêm uma localização implícita no seu léxico. Isso implica que os LOCs 
que aparecem com essa classe de verbos são argumentos das sentenças. Fazem parte dessa classe, verbos como aparecer, estar, chegar, sair, acontecer, ir, surgir, entre outros.

Além de verbos inacusativos, a autora também apresenta construções com LOCs na posição de SUJ com outros tipos de verbos:

(115) a. No bar da Faculdade de Letras apareceram os membros da Associção Académica.

b. No bar da Faculdade de Letras jantaram os membros da Associação.

c. Ontem foram vistas as crianças a roubar chocolates.

Em (115a), vemos mais um exemplo com o V inacusativo aparecer acompanhado de seu argumento NP/DP definido. Em (115b), a construção ocorre com um V inergativo, enquanto em (115c), com um VT passivizado.

Apesar de não nomear tais construções "inversões locativas”, Barbosa esboça uma análise para esse fenômeno no português. Seu trabalho nos dá uma idéia de como o fenômeno pode ser descrito no PB em termos do estatuto do LOC na construção como argumento da sentença, da função que esse LOC ocuparia como preenchedor da posição de SUJ, da natureza dos verbos que ocorrem na construção e da sua possível função discursiva através de um FOC apresentacional.

\subsubsection{A inversão locativa como um tipo de sentença apresentativa}

Em seu trabalho sobre a ordem VS no PB, Pilati (2002) descreve as ILs como um dos tipos de sentenças apresentativas, as quais denominou "orações apresentativodescritivas" (2002: 63). Para caracterizar a construção da IL, a autora baseia-se na descrição do fenômeno no inglês de L\&RH $(1992,1995)$, a qual apresentamos na seção 1.2. Sua análise é muito breve e seus exemplos não conseguem determinar todas as características da construção. O mais importante de seu trabalho é verificar como a inversão pode ser motivada por fatores discursivos.

O objetivo do estudo de Pilati é caracterizar sintática e semanticamente determinados tipos de sentenças que licenciam o SUJ pós-verbal no PB. A autora analisa sentenças declarativas com verbos finitos, mas sem a presença de TOPs na posição préverbal. Portanto, estão excluídas de seu trabalho orações em que o TOP veicula informação 
pressuposta no discurso (115a), ou em que o TOP é contrastivo (115b), como nos exemplos abaixo:

(115) a. O bolo, faz você. (2002: 62)

b. A nossa barraca, por exemplo, este ano faturou uma faixa de dez mil cruzeiros... Eu errei. Cem mil cruzeiros faturou nossa barraca ${ }^{18}$, certo? (Votre \& Naro 1989 apud Pilati 2002: 62)

Além disso, estão fora do âmbito de sua pesquisa sentenças com falsa inversão ou deslocamento à direita, como em (116), e construções em que um LOC selecionado ocupa a posição de SUJ e o argumento externo ocupa a posição pós-verbal, como em (117) (2002: 62):

(116) Ele 'tá lindo hoje, o seu cabelo.

(117) Essa casa entrou ladrão.

Aparentemente este último exemplo apresenta uma configuração de IL, apesar de ter sido eliminado dos dados de Pilati. Voltaremos a ele mais adiante (cf. seção 3.2).

As sentenças com SUJ invertido descritas em seu trabalho apresentam a ordem VOS ou VS, cujos SUJs e OBJs não podem ser interpretados como TOPs por não configurarem informação recuperada, não estarem separados do restante da oração por uma pausa entonacional e nem estarem sendo usados em contextos contrastivos. A autora classifica todas as sentenças que apresentam tais ordens e obedecem a essa restrição como sentenças apresentativas pois introduzem um novo referente no discurso. Para Pilati, a inversão do SUJ no PB tem essa função discursiva de inserir um novo elemento em um determinado contexto.

Seguindo Guéron (1980), a autora descreve as orações apresentativo-descritivas como tendo as seguintes características (2002: 65):

i. Possuem em LF (Logical Form) a estrutura (s Verbo $\left.{ }_{i}\left(\mathrm{~s}(\mathrm{NP})\left(\ldots \mathrm{v}_{\mathrm{i}} \ldots\right)_{\mathrm{s}}\right)_{\mathrm{s}}\right)$, em que o V é movido para a esquerda de $\mathrm{S}$;

\footnotetext{
${ }^{18}$ Grifo da autora.
} 
ii. O VP denota essencialmente o aparecimento do SUJ no mundo do discurso. Em sentenças apresentativas, pode haver SUJs temáticos ou não temáticos;

iii. Apresentam verbos existenciais ou outros verbos que podem ser tomados pragmaticamente como predicando nada mais que a aparição do SUJ na situação do discurso;

iv. Constituem um subgrupo das sentenças que descrevem eventos. Por isso, se uma sentença for usada apenas para descrever uma propriedade do SUJ, e não um evento, não pode ser considerada sentença apresentativa;

v. O SUJ é o constituinte mais acentuado, sem que disso resulte uma interpretação contrastiva;

vi. Apresentam restrições estruturais a VTs. Isso deve-se ao fato de que geralmente o OBJ que segue o V é marcado como FOC da sentença, que é conseqüentemente interpretada como uma oração predicativa. No entanto, quando o $\mathrm{V}$ e o $\mathrm{OBJ}$ se combinam e constituem uma forma verbal complexa, uma única unidade semântica, a oração contendo um VT pode ocorrer em contextos apresentativos.

Segundo Pilati, seus dados revelam que o SUJ das orações apresentativo-descritivas no PB não precisa ser um elemento totalmente novo na situação do discurso, podendo ser um elemento relativamente pouco familiar. Esse constituinte também geralmente recebe interpretação menos agentiva. Além disso, tais orações podem apresentar SUJs indefinidos ou definidos. Neste caso, o NP deve ser referencial tanto para o ouvinte quanto para o falante. Com o intuito de fazer uma descrição mais detalhada dessas sentenças, a autora classifica as orações apresentativo-descritivas em quatro grupos: 1. com inversão locativa, 2. com inversão em construções parentéticas, 3. com inversão narrativa e 4. com SUJ pósverbal sob o escopo do operador de foco situado no início da sentença.

Com relação à descrição da IL apresentada pela autora, esta traz muito pouco a acresecentar a tudo aquilo que já vimos no capítulo 1 e ao trabalho de Barbosa (1989). Infelizmente seus poucos exemplos não conseguem caracterizar o fenômeno no $\mathrm{PB}$, visto que praticamente todos eles ocorrem com verbos inergativos e trazem uma interpretação distorcida do estudo de L\&RH $(1992,1995)$ no qual se baseia (cf. Pilati 2002: 68-71). 


\subsubsection{A função discursiva da inversão do sujeito}

Quarezemin (2006), em seu recente trabalho sobre a focalização do SUJ no PB, também mostra que a inversão nessa língua tem uma função discursiva. Quando o SUJ aparece em posição pós-verbal na sentença, esse constituinte pode ser interpretado como FOC de informação e, dependendo da situação, como FOC contrastivo. A autora sugere que o PB não é uma língua rígida como as outras línguas românicas que sempre deixam o SUJ depois do V quando esse constituinte deve ser interpretado como FOC de informação.

Assim, seu estudo complementa o trabalho de Pilati (2002) no sentido de que faz uma caracterização dessa função discursiva das orações apresentativo-descritivas, a de ficalizar o SUJ. Primeiramente, Quarezemin mostra que o SUJ na posição pré-verbal pode ser interpretado tanto como FOC de informação, como ilustra (118), quanto como FOC contrastivo, como ilustra (119) (2006: 99):

(118) [F O João] comeu uma maçã.

(Quem comeu uma maçã?)

(119) [F A Maria ${ }^{19}$ ] comprou um carro (não a Ana).

Além disso, o SUJ focalizado em posição pré-verbal no PB pode aparecer em sentenças com verbos inacusativos, inergativos e transitivos, respectivamente (2006: 101):

(120) a. Quem chegou?

b. [F A Joana] chegou.

(121) a. Quem telefonou?

b. [F A Joana] telefonou.

(122) a. Quem beijou o João?

b. [F A Joana] beijou o João.

\footnotetext{
${ }^{19}$ A autora põe o constituinte focado em negrito para sinalizar o acento contrastivo na realização fonética.
} 
A autora mostra que os exemplos em (120)-(122) sugerem que o que faz o SUJ se posicionar depois do $\mathrm{V}$ em outras línguas românicas não atua com a mesma força no $\mathrm{PB}$, onde o SUJ pode preceder o V. Sua hipótese é que esta posição é spec, $I P$, a única posição A pré-verbal. Para sustentar tal hipótese, a autora mostra que o SUJ não está na periferia esquerda da sentença a partir dos exemplos em (123) (2006: 102):

(123) a. Quem ontem chegou tarde?

b. Ontem [F o Pedro] chegou tarde.

c. \# [F $\mathrm{O}$ Pedro] ontem chegou tarde.

Quarezemin explica que a inserção de um advérbio como ontem entre o SUJ e o V em (123c) torna a resposta inadequada para a pergunta (123a). Se o SUJ é lido como FOC de informação, o advérbio não pode ser inserido entre ele e o V. Caso isso ocorra, o SUJ ocupará uma posição no domínio $\mathrm{CP}$, podendo ser interpretado como TOP, e a sentença não poderá ser empregada em um contexto de pergunta-QU. Se, por outro lado, o advérbio ontem aparece mais à esquerda, como em (123b), indicando que o SUJ está em spec, IP, a resposta é adequada. Assim, o posicionamento do advérbio e do SUJ contribui para mostrar que o SUJ de informação se encontra em spec, IP e não na periferia esquerda da sentença.

Não sendo FOC de informação, o SUJ pode aparecer na periferia esquerda da sentença, como mostra a autora (2006: 102):

(124) a. O Pedro, ontem ele chegou às duas.

b. Não, [F a Maria] ontem chegou às duas.

No exemplo em (124a), o SUJ topicalizado o Pedro aparece na periferia esquerda da sentença. Por isso, não há nenhum problema no fato de o advérbio estar entre o SUJ e o V. De modo semelhante, em (124b), o SUJ a Maria é interpretado como FOC contrastivo, corrigindo a informação de que o Pedro tenha chegado às duas. Quarezemin, portanto, conclui que o SUJ focalizado em posição pré-verbal ocupa a posição spec, IP.

Assumindo que o traço [+FOC] de um constituinte vem do fato de este estar em spec, FocP e assumindo Belletti (2001), que postula que FocP se localiza na periferia 
esquerda de VP, Quarezemin propõe que a estrutura configuracional de uma sentença como em (122b) seja a representada abaixo (2006: 105):

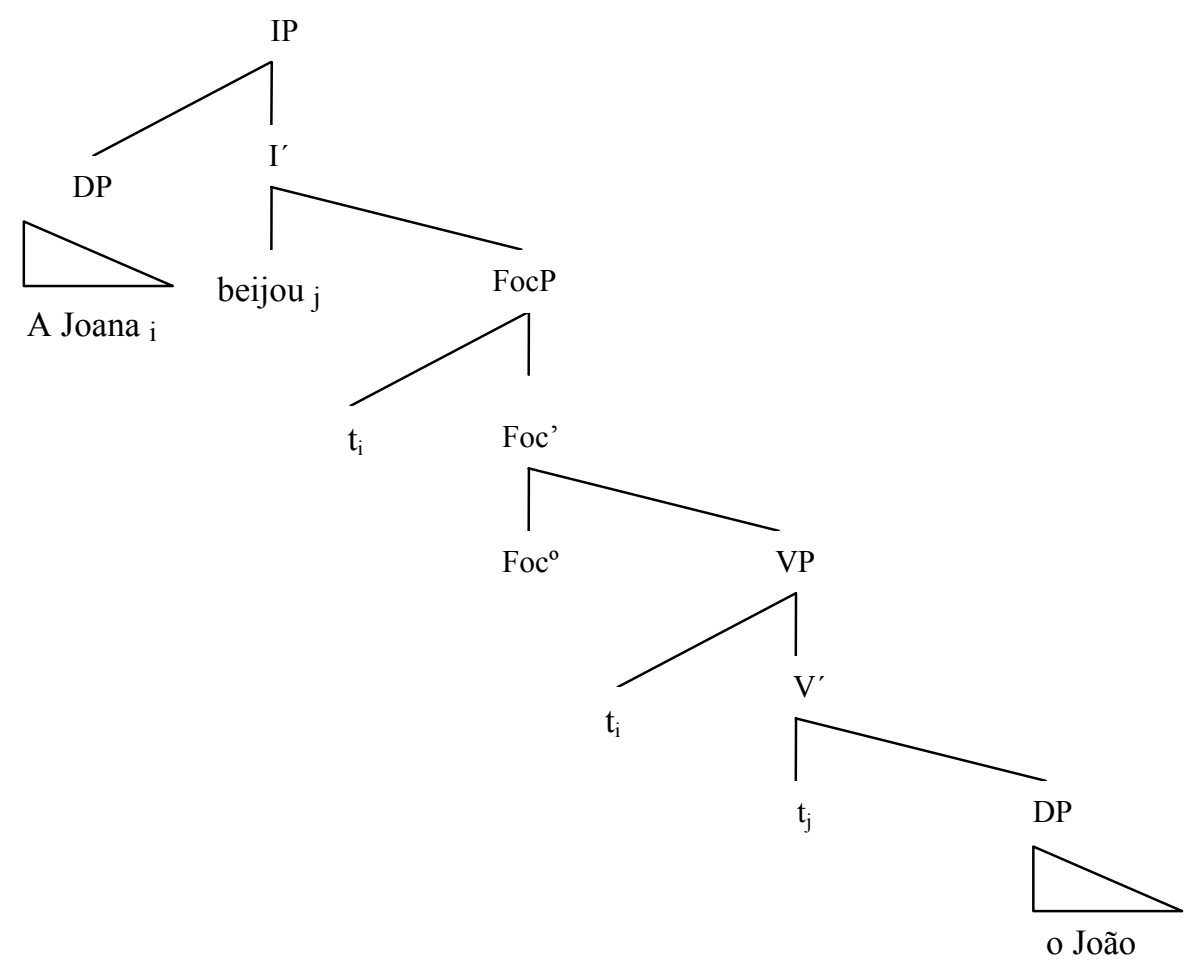

Assim, as sentenças com SUJ de informação pré-verbal satisfazem o critério Foco quando o SUJ passa por $s p e c, F o c P$ e entra em relação com o núcleo Foc. A autora assume a análise de Mioto (2003) para a posição spec, FocP como uma posição interna a IP e, conseqüentemente, uma posição A. Segundo Quarezemin, esse autor argumenta que um constituinte o qual deve conferir o seu Caso não pode sair de uma posição A, passar por uma posição A' e estacionar em outra posição A.

O SUJ interpretado como foco de informação também pode aparecer em posição pós-verbal em sentenças com verbos mono-argumentais (2006: 108):

(126) a. Quem chegou?

b. Chegou [F o Pedro].

(127) a. Quem telefonou?

b. Telefonou $[\mathrm{F}$ o Pedro]. 
Em se tratando dos verbos que contêm apenas um argumento, seja o V inacusativo ou inergativo, Quarezemin afirma que o PB apresenta uma opcionalidade entre manter o SUJ focalizado em posição pré-verbal ou pós-verbal. Se o mantém posposto, a configuração vai ser diferente de (125) em um ponto: o SUJ estaciona em spec, FocP acima do VP, como reproduzimos em (128) (2006: 108):

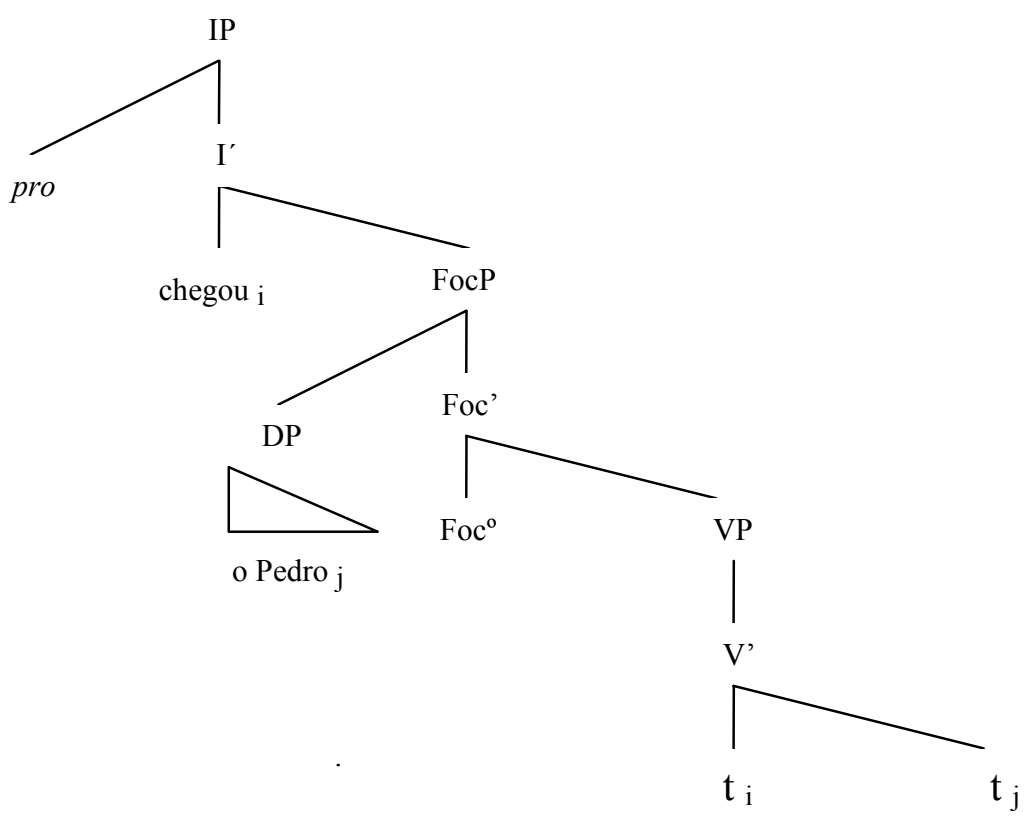

Seguindo Belletti (2001), Quarezemin insere um pro em spec, IP e o Caso nominativo do SUJ é verificado à distância. De acordo com a segunda autora, o que diferencia a inversão em línguas como o italiano e o PB é que, nesta última, pro não tem status de um pronome referencial, como ocorre com o italiano que permite a inversão livre do SUJ. No PB, encontramos sentenças com a inversão sem ter a concordância verbal, como no exemplo abaixo (2006: 109):

(129) Chegou os materiais.

A falta de concordância entre o SUJ posposto e o V mostra que pro em $\mathrm{PB}$ tem status de pronome expletivo e não, referencial. 
Nas sentenças com VTs, a autora observa que o SUJ dificilmente aparece em posição pós-verbal. Por isso, é normalmente focalizado antes do VT no PB. Caso isso não ocorra, a sentença é agramatical, como ilustra (130c-e) (2006: 110):

(130) a. Quem comprou o carro?

b. [F A Joana] comprou o carro.

c. * Comprou o carro [F a Joana].

d. * Comprou [F a Joana] o carro.

e. * O carro comprou [F Joana].

Segundo Quarezemin, o único contexto em que o SUJ interpretado como FOC de informação aparece depois do VT ocorre quando temos sentenças apresentativas, cuja informação relevante, não-pressuposta, aparece sempre no final das sentenças. Nesse contexto, o locutor nada mais faz do que apresentar alguém, como mostram seus seguintes exemplos (2006: 111):

(131) a. E agora, anima o público, [F o palhaço Biriba].

b. Vai cortar o bife [F o açougueiro].

Como vimos na seção anterior, as sentenças apresentativas foram analisadas por Pilati como contextos de inversão. Esta autora (2002: 66) propõe que as orações com VTs ocorrem em contextos apresentativos porque o $\mathrm{V}$ e o OBJ se combinam e consituem uma “forma verbal complexa, uma única unidade semântica".

Considerando que o PB é uma língua pro-drop parcial, Quarezemin também sugere que a inversão nessa língua ocorra de modo parcial. Devido a essa parcialidade, a autora conclui que o SUJ apenas é focalizado em posição pós-verbal quando a sentença contém verbos mono-argumentais ou tem função apresentativa.

\subsection{Uma proposta de análise}

Nesta seção, propomos uma análise para a construção da IL no PB considerando que não existe somente um único tipo de IL. Como vimos, Pilati (2002) pressupõe que 
todas as inversões sejam consideradas orações apresentativas. Não concordamos com essa afirmação e sugerimos que as sentenças agrupadas sob tal definição podem ser divididas em dois grupos: as inversões locativas propriamente ditas e as inversões locativas discursivas.

Argumentamos que as construções do primeiro tipo podem constituir focos largos nas situações discursivas, não enfatizando nenhuma informação específica, mas informando um fato "como um todo". Por outro lado, as construções do segundo tipo, apresentam um elemento ou veiculam alguma informação nova no discurso. Neste caso, o que licenciaria a inversão do SUJ seria sua função discursiva de introduzir um referente ou de trazer alguma informação não-familiar para o contexto.

A denominação inversões locativas propriamente ditas deve-se à predominância de verbos inacusativos nesse tipo de construção. Como vimos, a IL chegou a ser tratada como um fenômeno de inacusatividade em outras línguas devido às propriedades inerentes desses verbos que facilitariam a ocorrência do fenômeno. Considerando que um $\mathrm{V}$ inacusativo seleciona um único argumento na posição de OBJ e que este tem a possibilidade de permanecer in situ deixando livre a posição do SUJ para ser ocupada por um LOC PP, podemos admitir que essa ordem é uma ordem gerada "naturalmente" na língua.

Contudo, o movimento do LOC PP para a posição de SUJ (spec, IP) poderia ser questionada. Um possível argumento para explicar tal movimento viria do fato de que o PB hoje é considerado uma língua pro-drop parcial. Nesse sentido, a inversão do LOC constituiria uma estratégia de preenchimento da posição de SUJ para não deixá-la vazia foneticamente. A seguir, apresentamos alguns exemplos de ILs propriamente ditas:

(132) a. Na Anchieta tinha muito trânsito.

b. Na internet já saíram/ saiu as notas.

c. No escritório chegaram/ chegou as encomendas.

d. Na bilheteria acabaram/ acabou os ingressos.

Como podemos observar, os verbos que participam dessas sentenças são verbos inacusativos. Seguindo Kratzer (1988) e Barbosa (1989), admitimos que verbos inacusativos selecionam um argumento extra para localizações espaço-temporais. Sendo 
assim, consideramos que os PPs invertidos são $\operatorname{argumentos}$ do $\mathrm{V}$, e não adjuntos adverbiais, e recebem o papel $\theta$ locativo. Por sua vez, os DPs pós-verbais recebem o papel $\theta$ tema. Uma evidência para esse fato, vem da má formação de sentenças com LOCs adjuntos invertidos, como podemos ver nos exemplos abaixo:

(133) a. As crianças comiam no Mc Donald's.

b. ? No Mc Donald's comiam as crianças.

c. * No Mc Donald's as crianças comiam.

(134) a. O João trabalhava na IBM.

b. ?? Na IBM trabalhava o João.

c. Na IBM o João trabalhava.

(135) a. As crianças riram muito no show.

b. ?? No show riram muito as crianças.

c. * No show as crianças riram muito.

(136) a. O João 'tava bebendo na festa.

b. * Na festa 'tava bebendo o João.

c. * Na festa o João 'tava bebendo.

As sentenças (133a)-(136a) representam a ordem canônica no PB. Já em (133b)(136b), as sentenças divergem um pouco quanto ao seu grau de aceitabilidade, mas podemos dizer que todas elas não são exemplos de falas naturais e espontâneas do cotidiano, podendo ser realizadas em alguns determinados contextos. Por sua vez, como já havia notado Barbosa nos exemplos em (112) e (113), as sentenças em (133c)-(136c) não são possíveis pois quando o LOC e o SUJ aparecem antes do $\mathrm{V}$, o primeiro não pode anteceder o segundo.

Entretanto, um problema que nos surgiu foi como explicar a possibilidade de ILs com verbos inergativos e VTs passivizados, como nos exemplos em (137) e (138):

(137) a. No bar da Faculdade de Letras jantaram os membros da Associação. (Barbosa 1989) 
b. Naquelas cadeiras sentaram os noivos.

c. Neste brinquedo brincaram crianças de 0 a 6 anos.

(138) a. Nos documentos foram feitas todas as autenticações.

b. No supermercado foi visto um menino roubando chocolate.

Percebemos, a partir desses exemplos, que é possível haver ILs com verbos inergativos e VTs passivizados que, assim como aquelas construções com verbos inacusativos, não apresentam SUJs informacionais, mas apenas descrevem um evento como um todo quando interpretadas em contextos do tipo "O que aconteceu?". Nesse sentido, sugerimos que as ILs propriamente ditas são as construções de IL que constituem um FOC largo em um contexto discursivo mais geral, não necessariamente contendo um $\mathrm{V}$ inacusativo.

Nos moldes de Kempchinsky (2001), apresentamos a seguir uma evidência em favor de nossa análise através de contextos “O que aconteceu?":

(139) O que aconteceu?

a. [F $\mathrm{Na}$ Anchieta tinha muito trânsito].

b. [F No escritório chegaram/ chegou as encomendas].

c. [F No bar da Faculdade de Letras jantaram os membros da Associação].

d. [F Nos documentos foram feitas todas as autenticações].

(140) a. O que tinha na Anchieta?

b. Na Anchieta tinha [F muito trânsito].

(141) a. O que chegou no escritório?

b. No escritório chegaram/ chegou [F as encomendas].

(142) a. Quem jantou no bar da Faculdade de Letras?

b. No bar da Faculdade de Letras jantaram [F os membros da Associação].

(143) a. O que foi feito nos documentos?

b. Nos documentos foram feitas [F todas as autenticações]. 
Analisando os exemplos, percebemos que as sentenças em (139) constituem boas respostas a uma pergunta do tipo “O que aconteceu?". Isso nos mostra que, nesses contextos, essas sentenças constituem FOCs largos e não apresentam nenhuma função discursiva, mas apenas comunicam um fato.

No entanto, quando submetemos as mesmas sentenças a perguntas-QU, como em (140)-(143), percebemos que as orações não mais contituem focos largos, mas veiculam informação nova ou introduzem um referente na situação discursiva. Para descrevermos esses casos mais adequadamente, assumimos que as ILs que trazem o seu SUJ, indefinido ou não, como um FOC estreito apresentam uma função discursiva e são somente estas que podem ser consideradas sentenças apresentativas.

Adotando a análise de Quarezemin (2006) para a focalização do SUJ no PB, propomos que o DP pós-verbal, quando denota o SUJ de informação, ocupa a posição spec, FocP na periferia esquerda de VP. Assim, uma possível derivação para uma IL discursiva é a que representamos abaixo:

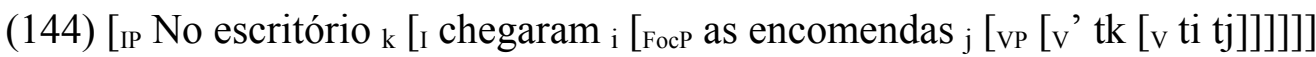

Estamos considerando em nossa análise que o PP LOC se meve para a posição de SUJ (spec, IP) e lá estaciona. Diferentemente da topicalização de PPs, na IL, o PP tem uma função gramatical, que é a de checar o EPP. Apesar de recuperar uma informação já dada no discurso, o PP da IL discursiva não pode ser interpretado como um TOP pois, além de sua função gramatical, não está separado do restante da oração por uma pausa entonacional e nem está sendo usado em contextos contrastivos.

Entretanto, reconhecemos que distinguir as ILs da topicalização de PPs no PB não é uma tarefa muito fácil. Consideremos a sentença (117) de Pilati (2002), reproduzida aqui em (145):

(145) Essa casa entrou ladrão.

Poderíamos pensar que essa sentença, a princípio, é um exemplo de IL, dependendo do contexto onde se enquadra, pode ser uma IL propriamente dita ou discursiva, afinal de 
contas, apresenta um argumento LOC no início da sentença e um SUJ DP em posição pósverbal. A diferença é que o LOC aqui não é um PP, e sim um DP.

Uma solução possível talvez fosse pensar que essa sentença é o resultado final de uma operação de IL que se transformou em uma construção de topicalização sem preposição e que teria sofrido a seguinte seqüência na língua:

(146) a. Ladrão entrou nessa casa.

b. Nessa casa entrou ladrão.

c. Essa casa entrou ladrão.

Uma outra possibilidade seria pensar a seqüência de outra forma:

(147) a. Ladrão entrou nessa casa.

b. Ladrão entrou hessa casa.

c. Essa casa entrou ladrão.

Nessa segunda possibilidade, o LOC perderia sua preposição durante algum ponto no processo de mudança da língua (147b). Por causa disso, o DP "restante" teria que se mover para a posição de SUJ para receber Caso (147b). Isso é o que se podia pensar em termos de GB. Um hipótese mais atual que explicaria o movimento do DP LOC seria assumir que esse DP se move para satisfazer o EPP.

Apresentamos essa breve reflexão para sugerir que o fenômeno da IL não é um fenômeno isolado e que uma descrição do fenômeno por si só não contribui muito para os estudos gramaticais da língua. Consideramos que a IL e as contruções de topicalização com e sem preposição talvez possam estar inter-relacionadas, apesar de constituirem fenômenos distintos. Um estudo mais aprofundado desses dois fenômenos poderia levar à confirmação ou não do traço EPP para o PB.

\subsection{Resumo do capítulo}

Na primeira seção deste capítulo, apresentamos alguns estudos importantes sobre a construção da IL no português, visto que ainda é um fenômeno pouco descrito nessa 
língua. Vimos que algumas primeiras impressões sobre a construção com relação ao estatuto do LOC como argumento da sentença, à função que esse LOC ocuparia como preenchedor da posição de SUJ, à natureza dos verbos que ocorrem na construção e à sua possível função discursiva através de um FOC apresentacional se confirmam.

Apontamos que Pilati (2002) considera a IL um tipo de oração apresentativodescritiva. Mostramos que nem todas as construções locativas podem ser consideradas como tais, propondo assim, que existem dois tipos de ILs: a IL propriamente dita e a IL discursiva. O primeiro tipo constitui-se como um foco largo e é apropriado em contextos do tipo "O que aconteceu?", não representando uma informação nova nem apresentando uma entidade na situação discursiva, mas somente comunica um fato ou um evento. $\mathrm{O}$ segundo tipo de tópico é aquele que apresenta uma função discursiva através do seu sujeito focado em posição pós-verbal, o qual veicula informação nova ou introduz um elemento no contexto.

Finalmente nossa análise para IL discursiva adota o estudo de Quarezemin (2006) sobre a focalização do sujeito, assumindo que essa inversão é licenciada pela sua função discursiva a qual pressupõe que o sujeito é um foco de informação que deve aparecer em posição pós-verbal. Apresentamos também uma reflexão acerca das construções de topicalização sem preposição que supostamente estariam relacionadas à IL. Nosso trabalho não chega a investigar o assunto a fundo, mas a partir disso, apontamos alguma direção para o estudo do traço EPP no PB. 


\section{Considerações Finais}

Nesta dissertação, apresentamos uma proposta de análise para o fenômeno da inversão locativa no português brasileiro. Primeiramente, fizemos uma descrição detalhada do fenômeno no inglês e no espanhol, línguas em que a construção já foi exaustivamente estudada. Oferecemos três análises sob perspectivas distintas, uma análise léxicofuncional, uma análise discursiva e uma análise minimalista, a partir das quais nos baseamos para pensar uma possível análise para a construção no PB.

No segundo capítulo, fizemos uma investigação no PB para poder ambientar o fenômeno numa perpectiva sincrônica da língua. Com relação ao parâmetro do sujeito nulo, vimos que atualmente o PB pode ser considerado uma língua pro-drop parcial, pois ainda mantém o SUJ nulo de $3^{\text {a }}$ pessoa na sua modalidade escrita, apesar do aumento expressivo do seu uso pleno principalmente na modalidade oral. Devido à sua condição de língua pro-drop parcial, é de se esperar que a inversão do SUJ também seja parcial, determinada por alguns fatores.

Vimos que o primeiro fator que estaria restringindo a existência de uma inversão livre no PB seria a perda da atribuição de Caso nominativo sob regência, apontado por Figueiredo Silva (1996). Pela sua análise, SUJs pós-verbais só podem ser licenciados em sentenças com verbos inacusativos. Assumindo a hipótese do Caso partitivo de Belletti (1988), a mesma autora sustenta que os DPs argumentos de verbos inacusativos recebem o Caso partitivo e, conseqüentemente, ficam submetidos ao efeito de definitude.

Para outros pesquisadores, como Kato e Tarallo (1993), outros fatores condicionantes para a existência de SUJs pospostos no PB seriam a presença obrigatória de verbos mono-argumentais nas inversões e a perda dos clíticos. No entanto, vimos, através de Pilati (2002) algumas construções em que a inversão ocorre sem que o verbo seja inacusativo e o DP argumento indefinido. E, ainda, que dependendo do contexto discursivo o SUJ pós-verbal não é TOP e nem está em adjunção com um pronome co-referente a ele em spec, IP.

Assim, assumimos que esses fatores apresentados não conseguem dar conta de explicar as ocorrências de SUJs pós-verbais no PB e que, ao contrário do que muitos pesquisadores dizem, a ordem VS não é uma ordem tão restrita assim. Parece que há outros fatores mais fortes que desencadeiam a inversão nessa língua, como a presença de um LOC 
ou um operador foco em posição inicial e a existência de uma função apresentativa dessas construções, que pressupõe que o SUJ invertido seja interpretado como o FOC da sentença.

No terceiro capítulo, apresentamos nossa análise sobre o fenômeno da IL. Mostramos que o PP LOC da construção é um argumento e não um adjunto do V e que, além disso, esse constituinte ocupa a posição $s p e c, I P$, constituindo-se como uma estratégia de preenchimento da posição de SUJ. Vimos que a construção não é restrita a verbos mono-argumentais, podendo ocorrer com VTs passivizados e que algumas ILs podem apresentar uma função discursiva.

Neste caso, atribuimos a essas construções a função discursiva de focalizar o seu SUJ informacional em posição pós-verbal. Quando isso acontece, tais construções são denominadas ILs discursivas. Caso contrário, quando apenas informam um evento ou fato, constituindo-se como FOC largo em contextos do tipo “O que aconteceu?", essas construções são denominadas ILs propriamente ditas.

Por fim, apresentamos uma breve reflexão sobre as construções de topicalização sem preposição que supostamente estariam relacionadas à IL. Além de propor uma análise para a IL no PB, nosso objetivo é mostrar a importância de tal fenômeno num âmbito maior dos estudos da gramática do $\mathrm{PB}$, considerando que a IL pode ser um indício que caracterizaria o PB como uma língua de traço EPP. Mas isso é tema para um próximo trabalho. 


\section{Referências Bibliográficas}

ANDREWS, A., \& C. MANNING. 1993. "Information spreading and levels of representation in LFG". Report No. CSLI-93-176. Stanford, CA: Center for the Study of Language and Information.

BAKER, M. 1991. On some subject/object non-asymmetries in Mohawk. Natural Language and Linguistic Theory 9:537-576.

BARBOSA, P. 1989. "Locative as Subjects ? Gathering some data from acquisition and parsing.” In: Linguistics 611.

BELLETTI, A. 1988. “The Case of Unaccusatives”. Linguistic Inquiry, vol. 19. pp.1-34. 2001. "Aspects of the low IP area”, ms, Universitá di Siena.

BERLINCK, R. 1989. “A construção V SN no português do Brasil: uma viagem diacrônica do fenômeno da ordem". In: F. Tarallo (org), Fotografias sociolingüisticas. Campinas: Editora da UNICAMP.

BIRNER, B. J. 1992. “The Discourse Function of Inversion in English.” Dissertação de Doutorado, Northwestern University, Evanston, Ill. . 1994. "Information Status and Word Order: An Analysis of English Inversion." Language 70:233-259.

BOLINGER, D. 1977. Form and Meaning. London: Longman.

BOWERS, J. S. 1976. On surface structure grammatical relations and the structurepreserving hypothesis. Linguistic Analysis 2:225-242.

BRESNAN, J. 1994. "Locative Inversion and the Architecture of Universal Grammar." Language 70:72-131.

\& J.M. KANERVA. 1989. "Locative Inversion in Chichewa: A Case Study of Factorization in Grammar." Linguistic Inquiry 20:1-50.

BURZIO, L. 1986. Italian Syntax: A Government-Binding Approach. Dordrecht: Reidel.

CASIELLES-SUÁREZ, E. 1999. "Notes on the Topic-Focus Articulation". Advances in Hispanic Linguistics ed. by Javier Gutiérrez-Rexach and Fernando Martínez-Gil, 346-363. Somerville, Mass.: Cascadilla Press.

CHOMSKY, N. 1981. Lectures on government and binding. Dordrecht: Foris. 1986. Knowledge of Language: Its Nature, Origin, and Use, Praeger, New York. 1995. The Minimalist Program. Cambridge, Mass.: MIT Press. 1998. “Minimalist Inquiries: The Framework”. Mss., MIT. 
\& H. LASNIK. 1977. "Filters and Control”. Linguistic Inquiry, vol. 8, pp. 425-504.

COLLINS, C. 1997. Local Economy. Cambridge, Mass.: MIT Press.

CONTRERAS, H. 1987. “Small Clauses in Spanish and English”. In: Natural Language \& Linguistic Theory. Springer Netherlands, vol. 5, $\mathrm{n}^{\circ}$ 2, pp. 225-243.

COOPMANS, P. 1989. "Where Stylistic and Syntactic Processes Meet: Locative Inversion in English." Language 65:728-51.

DUARTE. M. E. L. 1995. A perda do princípio "Evite Pronome" no português brasileiro. Tese de Doutorado, UNICAMP.

. 1996. "Do pronome nulo ao pronome pleno: a trajetória do sujeito no português do Brasil”. In: I. Roberts, M. Kato (orgs), Português Brasileiro: uma viagem diacrônica. Campinas: Editora da UNICAMP.

FIGUEIREDO SILVA, M. 1996. A posição do sujeito no Português Brasileiro - frases finitas e infinitivas. Campinas: Editora da UNICAMP.

GOODALL, G. 1991. "On the Status of Spec of IP”. Proceedings of the Tenth West Coast Conference on Formal Linguistics ed. by Dawn Bates. Stanford, CA: CSLI Publications.

GUÉRON, J. 1980. “On the Syntax and Semantics of PP Extraposition”. Linguistic Inquiry 11 (4): 637-678.

HOEKSTRA, T., \& R. MULDER. 1990. Unergatives as copular verbs: Locational and existential predication. Linguistic Review 7:1-79.

JACKENDOFF, R. 1993. On the role of conceptual structure in argument selection: A reply to Emonds. Natural Language and Linguistic Theory 11:279-312.

KAC, M. B. 1978. Corepresentation of grammatical structure. Minneapolis: University of Minnesota Press.

KATO, M. 1999. "Strong and weak pronominals and null subject parameter". PROBUS, vol. $11, \mathrm{n}^{\circ} 1$, pp. 1-38.

. 2000. "A restrição de Mono-Argumentalidade da Ordem VS no Português do Brasil”. In: C. Mioto, H. M. de Melo Moura, R. Pires de Oliveira, eds., Fórum Lingüístico. Vol. 2, n 2. Florianópolis, Pós-graduação em Lingüística, UFSC. pp. 97-127.

, \& F. TARALLO. 1993. "The loss of VS syntax in Brazilian Portuguese”. In: I. V. Koch \& B. Schliebe-Lange (orgs) Linguistik in Bresil. Tübingen: Nyemeyer. 
KEMPCHINSKY, P. 2002. "Locative Inversion, PP Topicalization and the EPP”. Current Issues in Linguistic Theory: Selected proceedings of the 29th Linguistic Symposium in Romance Languages, eds. Diana Cresti, et al. Amsterdam/Philadelphia: John Benjamins. KIM, J. 1999. "Locative Inversion and Optional Features". Paper presented at West Coast Conference on Formal Linguistics, University of Arizona, Tucson, AZ.

KITAGAWA, Y. 1986. Subject in Japanese and English, Dissertação de Doutorado, University of Massachusetts, Amherst.

KOOPMAN, H., \& D. SPORTICHE. 1991. "The Position of Subjects.” Language. Vol. $85, n^{\circ} 2$. pp. $211-258$.

KRATZER, A. 1988. "Stage-level and individual-level predicates”. University of Mass. Amherst.

KURODA, S.Y.1988. “Whether We Agree or Not.” Lingvisticae Investigationes 12:1-47.

LARSON, R. 1988. “On the Double Object Construction”. Linguistic Inquiry 19:335-392.

LEVIN, B. 1991. Locative inversion: A problem for the unaccusative hypothesis ? Evanston, IL: Northwestern University, MS.

\& M. RAPPAPORT HOVAV. 1992. Unaccusativity: At the syntax-semantics interface (Nov. 1992 draft). Evanston, IL, \& Ramat Gan, Israel: Northwestern University \& Bar Ilan University, MS.

\& M. RAPPAPORT HOVAV. 1995. Unaccusativity: At the Syntax-Lexical Semantics Interface. Cambridge, Mass.: MIT Press.

LEVIN, L. 1986. "Operations on Lexical Forms: Unaccusative Rules in Germanic Languages.” Dissertação de Doutorado, MIT, Cambridge, Mass.

MIOTO, C. 2003. "Focalização e Quantificação". Revista Letras. Curitiba: Editora UFPR, 61, pp. 169-189.

ORDOÑES, F. 1997. Word Order and Clause Structure in Spanish and other Romance Languages. Dissertação de Doutorado, CUNY.

. 1998. "Postverbal Asymmentries in Spanish". Natural Language and Linguistic Theory. vol. 16, $\mathrm{n}^{\circ}$ 2. pp. 313-346.

PENHALLURICK, J. 1984. "Full-Verb Inversion in English." Australian Journal of Linguistics 4:33-56. 
PERLMUTTER, D. M. 1978. "Impersonal Passives and the Unaccusative Hypothesis." In Proceedings of the Fourth Annual Meeting of the Berkeley Linguistics Society, 157-189. Berkeley Linguistics Society, University of California, Berkeley.

PILATI, E. N. S. 2002. Sobre a Ordem Verbo-Sujeito no Português do Brasil. Dissertação de Mestrado. UnB ( Universidade de Brasília ).

PONTES, E. 1987. O Tópico no Português do Brasil. Campinas: Editora Pontes.

QUAREZEMIN, S. 2006. A focalização do Sujeito no Português Brasileiro. Dissertação de Mestrado. UFSC ( Universidade Federal de Santa Catarina ).

ROCHEMONT, M. S., \& P. CULICOVER. 1990. English focus constructions and the theory of grammar. Cambridge: Cambridge University Press.

SADOCK, J. M. 1991. Autolexical syntax: A theory of parallel grammatical representations. Chicago: University of Chicago Press.

SPEAS, M. 1986. Adjunctions and Projections in Syntax. Dissertação de Doutorado, MIT. 1990. Phrase structure in natural language. Dordrecht: Kluwer.

SPORTICHE, D. 1988. A Theory of Floating Quantifiers and Its Corollaries for Constituent Structure. Linguistic Inquiry 19:425-449.

THRÁINSSON, H. 1980. On complementation in Icelandic. New York: Garland.

VINCENZI, M. De 1989. Syntactic Parsing Strategies in a Null Subject Language. Dissertação de Doutorado. University of Mass. Amherst.

ZAGONA, K. 1982. "Government and Proper Government of Verbal Projections." Dissertação de Doutorado, University of Washington, Seattle.

ZUBIZARRETA, M. L. 1998. Prosody, Focus, and Word Order. Cambridge, Mass.: MIT Press. 